\title{
Medicinal plants with antioxidant and free radical scavenging effects (part 2): plant based review
}

\author{
Prof Dr Ali Esmail Al-Snafi \\ Department of Pharmacology, College of Medicine, Thi qar University
}

\begin{abstract}
Previous studies showed that a wide range of medicinal plants exerted antioxidant and free radical scavenging activity. These plants included: Achillea santolina, Adiantum capillus-veneris, Agrimonia eupatoria, Ailanthus altissima, Alhagi maurorum, Allium cepa, Allium porrum, Allium sativum, Allium schoenoprasum, Alpinia galangal, Althaea officinalis, Ammannia baccifera, Ammi visnaga, Anchusa italica, Anchusa strigosa, Anethum graveolens, Antirrhinum majus, Arachis hypogaea, Arctium lappa, Artemisia campestris, Asparagus officinalis, Astragalus hamosus, Avena sativa, Bacopa monniera, Ballota nigra, Bauhinia variegata, Bellis perenni, Bidens tripartite, Brassica rapa, Bryophyllum calycinum, Caesalpinia crista Calamintha graveolens, Calendula officinalis, Calotropis procera, Canna indica, Capparis spinosa, Capsicum annuum, Capsicum frutescens, Carthamus tinctorius, Carum carvi, Cassia occidentalis, Casuarina equisetifolia, Centaurea cyanus, Chenopodium album and Chrozophora tinctoria. This review was designed to highlight the antioxidant effects of medicinal plants as a second part of our previous review.
\end{abstract}

Keywords: antioxidant, free radical scavenging, medicinal plant, herbs

\section{INTRODUCTION}

As a result of accumulated experience from the past generations, today, all the world's cultures have an extensive knowledge of herbal medicine. Two thirds of the new chemicals identified yearly were extracted from higher plants. $75 \%$ of the world's population used plants for therapy and prevention. In the US, where chemical synthesis dominates the pharmaceutical industry, $25 \%$ of the pharmaceuticals are based on plant-derived chemicals [1]. Previous studies showed that a wide range of medicinal plants exerted antioxidant and free radical scavenging activity. These plants included: Achillea santolina [2], Adiantum capillus-veneris [3], Agrimonia eupatoria [4], Ailanthus altissima [5], Alhagi maurorum [6], Allium species [7], Alpinia galangal [8], Althaea officinalis[9], Ammannia baccifera[10], Ammi visnaga [11], Anchusa species[12], Anethum graveolens [13], Antemis nobilis [14], Antirrhinum majus [15], Arachis hypogaea [16], Arctium lappa [17], Artemisia campestris [18], Asparagus officinalis [19], Astragalus hamosus [20], Avena sativa [21], Bacopa monniera [22], Ballota nigra [23], Bauhinia variegate [24], Bellis perenni [25], Bidens tripartite [26], Brassica rapa [27], Bryophyllum calycinum [28], Caesalpinia crista[29], Calamintha graveolens [30], Calendula officinalis [31], Calotropis procera [32], Canna indica [33], Capparis spinosa [34], Capsicum species [35], Carthamus tinctorius [36], Carum carvi [37], Cassia occidentalis [38], Casuarina equisetifolia [39], Centaurea cyanus [40], Chenopodium album [41] and Chrozophora tinctoria [42]. This review was designed to highlight the antioxidant effects of medicinal plants as a second part of our previous review [43].

\section{II- PLANTS POSSESSED ANTIOXIDANT ACTIVITY}

\section{Cicer arietinum}

The free radicals scavenging, antioxidant properties and intestinal $\alpha$-glucosidase inhibitory activity of methanol extract of two varieties of Cicer arietinum were evaluated. Compared with raw seeds increase in total polyphenol and flavonoids concentration in green gram sprouts and Kabuli Chana sprouts (KCs) were recorded. Total protein concentrations in sprouts did not differ from non-sprouted grains. 2,2'- Azinobis (3-ethyl benzthiazoline-6-sulphonic acid) cation scavenging activity was more than twice in Bengal gram sprouts of (BGs) and KCs than their raw seeds. 2,2-diphenyl-1-picrylhydrazyl, hydrogen peroxide scavenging, nitro blue tetrazolium reducing and glucose-induced $\mathrm{Hb}$-glycation inhibitory activity did not differ from non-sprouted raw grains. Increase in rat intestinal $\alpha$-glucosidase inhibitory activity was observed in BGs and KCs. BGs significantly mitigated first $30 \mathrm{~min}$ starch-induced postprandial glycemic excursions and reduced $2 \mathrm{~h}$ postprandial glycemic load [44-45].

The extent of free radical scavenging properties and antioxidant effects of crude extracts of sprouted Cicer arietinum (Chick pea/Chana/Bengal gram) seeds were evaluated. Two main varieties of Cicer arietinum seeds viz. Kabuli-Chana (cream seed-coat) and Bengal gram (brown seed-coat) were examined and compared for their free radical scavenging properties and antioxidant effects. Free radical scavenging properties were evaluated against stable 2, 2-diphenyl-1-picrylhydrazyl radical (DPPH) and hydrogen peroxide radical and the 
extent of antioxidant effect was assessed by lipid peroxidation induced by ferrous sulphate on the lipid present in the liver homogenate. The results showed that the two Cicer arietinum extracts were differed in their capacities to quench or inhibit DPPH, hydrogen peroxide and lipid peroxide. Brown colored Cicer arietinum sprouts showed the greatest activity against DPPH radicals, hydrogen peroxide radicals and lipid peroxide compared to the cream variety [45-46].

The root of Cicer arietinum was extracted using solvents of different polarities and explored for in vitro free radical scavenging activity. Preliminary assays of three different extracts of Cicer arietinum root showed that the extracts possess electron donating ability and reduction of ferric ion to ferrous in a cell free system at $\mathrm{pH}-7.4$. It has also been found from total antioxidant capacity as assessed by reduction of molybdate showed Cicer arietinum root extracts to possess (standard) ascorbic acid equivalents per milligrams of the extracts. Hydroalcoholic root extract was found more effective when compared to alcoholic and water extracts in scavenging 1, 1-diphenyl-2-picrylhydrazyl, reducing ferric ion and molybdate reduction in antioxidant capacity. A significant correlations exist between extract concentrations and percentage scavenging activity of radicals in all models [47].

The lectin was isolated from the seeds of Cicer arietinum. The antioxidant activity of the eluted fractions containing lectin was determined. DPPH scavenging activity of isolated lectin from Cicer arietinum Linn. at concentration of $10,100,250,500$ and $1000(\mu \mathrm{g} / \mathrm{ml})$ were $19.5 \pm 4.29,34.2 \pm 0.77,42.0 \pm 0.3554 .3$ \pm 1.14 and $69.2 \pm 3.67$ ( \% Inhibition) [48].

Extract and its different fractions of mature pod wall of Cicer arietinum Linn. were assessed for their antioxidant activity by in vitro methods. Antioxidant activity was studied using 1, 1- Diphenyl-2-Picrylhydrazyl (DPPH), nitric oxide scavenging activity, hydrogen peroxide scavenging activity, reducing power assay. Results showed that extracts and fractions exhibited significant DPPH, nitric oxide and hydrogen peroxide activity [49]. Rats treated with $\mathrm{CCl}_{4}$ showed a significant decrease in superoxide dismutase, catalase, GSH, increased MDA levels. The group of rats treated with petroleum ether extract of Cicer arietinum (200mg/kg, po, once daily) showed no significance increase in catalase, GSH, SOD and no significant decrease in MDA levels. Whereas group treated with low doses of methanol and aqueous extracts $(200 \mathrm{mg} / \mathrm{kg})$ showed a significant increase in the catalase, GSH, GST and a significant decrease in MDA. On the other hand, 250 and $500 \mathrm{mg} / \mathrm{kg}$ of ethanolic seeds extract of Cicer arietinum showed hepatoprotective against the paracetamol induced hepatotoxicity in rats [50-51].

\section{Cihorium intybus}

The Cihorium intybus seed extract/fractions exhibited good DPPH radical scavenging activity, with $\mathrm{IC}_{50}$ ranging from 21.28-72.14 $\mu \mathrm{g} / \mathrm{ml} .100 \%$ methanolic extract and ethylacetate fraction exhibited the maximum antioxidant activity. However, the results showed significant $(\mathrm{p}<0.01)$ variations in the antioxidant activities of Cihorium intybus seeds solvent extract/fractions [52].

The efficacy of Cihorium intybus leaves powder to minimize the oxidative damage, causing brain dysfunction in diabetes, was studied in rats. Diabetes was induced with alloxan monohydrate. Oxidative damage, impairment of oxidative defense and neuronal activity were investigated in cerebral hemispheres $48 \mathrm{~h}$ after alloxan administration. Diabetes caused an elevation $(\mathrm{p}<0.001)$ of blood glucose, protein carbonyl content $(\operatorname{PrC})$ and lipid peroxidation. The brain level of the antioxidant enzyme, catalase (CAT), reduced glutathione (GSH) and acetyl cholinesterase (AChE) exhibited significant decline in alloxan-diabetes. Feeding with dried powder leaves of Cihorium intybus decreased blood glucose level to near normal level and minimize the impairment of oxidative defense [53-54].

The antioxidant properties of Cichorium intybus var. Silvestre, from Italy, were investigated in vitro. Vegetable juices were obtained by centrifugation, and (1) filtration at 2 degrees C; (2) filtration at 25 degrees $\mathrm{C}$, and stored for $3 \mathrm{~h}$; (3) boiled for $30 \mathrm{~min}$ at 102 degrees $\mathrm{C}$, and then analysed. The antioxidant properties were evaluated in vitro as antioxidant activity (AA) (model system beta-carotene-linoleic acid) and ex vivo as protective activity (PA) against rat liver cell microsome lipid peroxidation measured as 2-thiobarbituric acidreactive substances (TBA-RS) generated by peroxide degradation. All the vegetable juices showed high but very variable AA $(>83 \%)$ and PA (> 64\%). After dialysis and analysis of fractions it was shown that the vegetable contained both biological antioxidant and prooxidant compounds. The prooxidants had $\mathrm{MW}<3000$, the most potent antioxidants compound $(\mathrm{PA}=100 \%)$ had $\mathrm{MW}>15000$ [54-55].

Statistically significant differences $(\mathrm{p}<0.05)$ were observed in the DPPH radical scavenging capacities of different parts of Cichorium intybus . Leaves were found to possess comparatively good free radical scavenging capacity due to higher $\mathrm{DPPH}$ radical inhibition and lower $\mathrm{IC}_{50}$ value. However, all parts of Cichorium intybus showed lower percentage of DPPH radical inhibition and higher $\mathrm{IC}_{50}$ values as compared to those of Trolox and ascorbic acid taken as standard antioxidants [56].

Cell injury associated with reactive oxygen species (ROS) has been reported in various muscular disorders. Cichorium intybus extract reduced $\mathrm{H}_{2} \mathrm{O}_{2}$-induced viability loss in myoblasts, inhibited oxidative stress-induced apoptosis and increased intracellular heat shock protein 70 (Hsp 70) expression. Cichorium 
intybus extract also inhibited the level of intracellular ceramide. These results indicate that Cichorium intybus extract may prevent skeletal muscle atrophy by inducing the expression of Hsp 70 and inhibiting the level of ceramide [57].

The Total phenolic compounds increased from 22.34 to $27.87 \mathrm{mg} \mathrm{GAE}$ (gallic acid equivalents)/100 g (dry extracts) with increasing solvent polarity. The half inhibition concentration $\left(\mathrm{IC}_{50} \mu \mathrm{g} / \mathrm{ml}\right)$ of the radical scavenging activity of the chicory extracts ranged from 281.00 to $983.33 \mu \mathrm{g} / \mathrm{ml}$. The content of caffeoylquinic acids of root extract, which was extracted by the optimal combination was $0.104 \%$ [58].

\section{Citrullus colocynthis}

Flavonoids, isosaponarin, isovitexin and isoorientin 3'-O-methyl ether, isolated from the fruits of Citrullus colocynthis showed significant antioxidant properties [59-60].

The methanolic fruit extract of Citrullus colocynthis was screened to evaluate its free-radical scavenging effect. The highest antioxidant and free radical scavenging ability of the fruit extract was observed at a concentration of $2500 \mathrm{mg} / \mathrm{ml}$ [61].

The antioxidant effects of Citrullus colocynthis seeds extracts [a crude aqueous extract (E1), a defatted aqueous extract (E2), a hydromethanolic extract (HM), an ethyl acetate extract (EA) and a $n$-butanol extract (nB)] were studied at a concentration of $2000 \mu \mathrm{g} / \mathrm{ml}$ in a 1,1-diphenyl-2-picrylhydrazyl assay, a reducing percentage of $88.8 \%$ with EA, $74.5 \%$ with $\mathrm{HM}$ and $66.2 \%$ with E1 were recorded, with a corresponding $\mathrm{IC}_{50}$ of 350,580 and $500 \mu \mathrm{g} / \mathrm{ml}$ respectively as compared to $1.1 \mu \mathrm{g} / \mathrm{ml}$ for ascorbic acid [62].

Antioxidant activity of Citrullus colocynthis seed methanolic extract was studied spectrophotometrically by 1 , 1-diphenyl-2-picryl hydrazyl and hydrogen peroxide free radical scavenging method. The methanolic seed extract of Citrullus colocynthis showed maximum percentage inhibition of 79.4 and $72.4 \%$ by 1, 1-diphenyl2-picryl hydrazyl and hydrogen peroxide method respectively at $300 \mu \mathrm{g} / \mathrm{ml}$ [63].

In vitro antioxidant studies revealed that, maximum percentage inhibition of DPPH radicals by methanolic extract of Citrullus colocynthis fruits (MECC) was $62 \%$ at $800 \mu \mathrm{g} / \mathrm{ml}$. In the nitric oxide radical scavenging model, the maximum percentage inhibition by MECC is about $56 \%$ at $800 \mu \mathrm{g} / \mathrm{ml}$, MECC demonstrated dose dependent antioxidant activity comparable with Ascorbic acid [64].

\section{Citrus species:}

The DPPH radical scavenging activities of the leaf extracts and leaf essential oil of Citrus aurantifolia were investigated on 1, 1- diphenyl-2-picrylhydrazyl (DPPH) radical. Among the leaf extracts and leaf essential oil of $C$. aurantifolia studied, leaf methanol and ethyl acetate extracts showed potent scavenging activity [65].

The antioxidant effects of fresh juice and peel extract of Citrus aurantifolia was evaluated. $5 \mu$ of lime juice didn't change LDL oxidation. $10 \mu \mathrm{l}$ of juice inhibited LDL oxidation, and with increasing the juice concentration, LDL was oxidized faster. Both juice and peel demonstrated antioxidant properties [66].

The antioxidant properties of Citrus aurantifolia peel and leaves from different areas were studied using the diphenyl picryl hydrazyl, 2,2'-azino-bis(3-ethyl benzo thiazoline-6-sulfonic acid) and ferric reducing ability of plasma assays, and the $\beta$-carotene bleaching test. Methanol extracts of the peel and leaves demonstrated the strongest radical scavenging activity. A similar trend was observed with the reducing ability, with values from 112.1 to $146.0 \mu \mathrm{mol} / \mathrm{l} \mathrm{Fe} / \mathrm{g}$ [67].

The in vitro antioxidant activities of juices of both unripen and ripen Citrus aurantifolia was investigated. Juices were extracted from fresh ripen and unripen fruits by mechanical squeezing and were used for antioxidant study. The antioxidant activity of juice was evaluated by using the free radical scavenging activity of 1, 1-diphenyl-2-picrylhydrazyl radical (DPPH), total antioxidant capacity (TAC) by the phosphomolybdenum method. Unripen juices showed more antioxidant scavenging activity as compared to ripen juices. The lower antioxidant activity of ripe fruit juices could be due to the possible reduction in the ascorbic acid and total phenolic content during ripening. The unripe juice showed a range of 3.45 to $28.23 \%$ at 25 to $200 \mu \mathrm{l}$ concentrations respectively. At the same concentration range the value for the ripe juice was found to be 2.08 to $23.56 \%$ respectively. The total antioxidant content in terms of ascorbic acid (mg/ml) was 0.178 and $0.127 \mathrm{mg} / \mathrm{ml}$ for unripe and ripen juices respectively [68].

Various in vitro and ex vivo studies were performed to estimate the polyphenols and flavonoids in the Citrus limonum pulp and peel. The reducing power, free radical scavenging activity and lipid peroxide inhibition were also investigated. The lemon peel was found to have a slightly greater contents of polyphenols and flavonoids. The peel extracts also showed better reducing power and higher free radical scavenging activity. The peel extracts gave $82.3 \%$ of inhibition towards lipid peroxidation, when compared to the pulp extracts which showed an inhibition of 78.2\% [69].Citrus limon essential oil (EO) showed strong antioxidant activity in mice. Furthermore, it also possessed scavenger activity in all in vitro tests [70].Essential oil of Citrus limon leaves reduced the lipid peroxidation and nitrite content as well as increase the glutathione reduced (GSH) levels and enzymatic antioxidant activities (super-oxide dismutase, catalase and glutathione peroxidase) in mice hippocampus. These findings strongly support the hypothesis that oxidative stress in hippocampus might occur 
during neurodegenerative diseases, proving that hippocampal damage induced by the oxidative process played a crucial role in brain disorders, which implies that a neuroprotective effect could be achieved using Citrus limon essential oil as antioxidant treatment [71].The action of Citrus limonum essential oil to control free radicalinduced lipid peroxidation and preventing tissue damage in skin was investigated. The superoxide anion scavenging activity of essential oil was evaluated by the enzymatic hypoxanthine/xanthine oxidase system. The same oil diluted in DMSO or grape-seed oil was spread on the face of human volunteers after UV exposition. A sample of skin lipids was collected and the presence of peroxyl radicals was detected based on the measurement of light emitted (chemiluminescence) when the excited carbonyl and singlet oxygen decay to ground state. Data demonstrated that the lemon essential oil was more active than $\alpha$-tocopherol against $\mathrm{O}^{2}$ - and peroxide free radical inhibition at 1:100 dilution [72].

The antioxidant activity of $70 \%$ aqueous methanol extract of the defatted powdered leaves of Citrus medica was calculated to be $102.9 \mu \mathrm{g} / \mathrm{ml}$. It also exerted significant reduction in blood glucose level to $(105.2 \pm 8.35)$ in diabetic rats after one month of treatment with a dose of $200 \mathrm{mg} / \mathrm{kg}$ and to $(87.4 \pm 6.30)$ with $400 \mathrm{mg}$. The authors concluded that the methanol extract of the defatted powdered leaves of Citrus medica exhibited significant antihyperglycemic activity which might be attributed to the presence of flavonoid compounds [73].

The extract of Citrus medica showed significant antioxidant activity verified by different assays (DPPH test, $\beta$-carotene bleaching test and bovine brain peroxidation assay) in a dose dependent manner as compared to ascorbic acid [74-75].The antioxidant potential of ethanolic extract of Citrus medica L. peels (ECMP) extract was studied on Thiobarbituric Acid Reactive Substances (TBARS) as index of lipid peroxidation and on the glycemic control in streptozotocin induced diabetic rats. ECMP was used in as (200 and $400 \mathrm{mg} / \mathrm{kg}$ ). The elevated level of blood glucose, glycosylated hemoglobin, TBARS observed in diabetic rats were significantly decreased after treatment with ECMP for 8 weeks in diabetic rats. From the results, the ethanolic extract of Citrus medica L. peels possessed potent antioxidant and antidiabetic properties [76].

The results of antioxidant activity of peel essential oil of Citrus limetta var. Mitha showed that it was able to reduce the stable radical 1- diphenyl-2-picrylhydrazyl (DPPH) to yellow-colored DPPH-H reaching $87.77 \%$ of DPPH scavenging effect at its $100 \%$ concentration comparative to ascorbic acid as reference standard being a strong antioxidant reagent [77].

The in vitro antioxidant activity of the methanol extracts of Citrus limetta fruit peel (MECL) was evaluated in different models such as DPPH, superoxide radical and nitric oxide radical scavenging activity and inhibition of lipid peroxidation. The total phenolic compounds present in the extracts were estimated by FolinCiocalteu's reagent. The extract showed good free radical scavenging activity in a dose dependent manner. The $\mathrm{IC}_{50}$ values for $\mathrm{DPPH}$, superoxide radical, nitric oxide radical inhibition and lipid peroxidation assays of MECL were 7.36, 9.36, 136.45 and 111 respectively. Measurement of total phenolic compounds by Folin- Ciocalteu's reagent indicated that $1 \mathrm{mg}$ extract contains $126.85 \mu \mathrm{g}$ equivalent of pyrocatechol in MECL [78].

Extracts prepared from the Citrus limetta fruit peels were studied for antioxidant and anti- inflammatory activity using in vitro bioassays. Among all extracts, ethanol extract of Citrus limetta fruit peels has shown promising anti-oxidant and anti-inflammatory activity [79].

It was reported that juice and edible parts of Citrus sinensis of different origin and from different varieties exerted antioxidant activity, while, the peel extracts were found to have a good total radical antioxidative potential [80-81]. Methanolic extracts of 6 citrus species ( $C$. sinensis var. Washington Navel, $C$. sinensis var. Valencia, $C$. reticulata var. Page, $C$. sinensis var. Sungin, $C$. paradise and $C$. aurantium) peels and tissues growing in Pakistan were investigated for their antioxidant activity by DPPH method. IC ${ }_{50}$ for antioxidant activity ranged from $0.8-4.7 \mathrm{mg} / \mathrm{ml}$. Total phenolic content of the citrus spp. samples (based on folin Ciocalteu method) varied from 99.4 to $229.5 \mathrm{mg}$ gallic acid equivalent/g of extract and flavonoids content (based on colorimetric $\mathrm{AlCl}_{3}$ method) varied from 0.2 to $25.7 \mathrm{mg}$ quercetin equivalent/g of extract. There were no correlation between the total phenolic and/ or flavonoids contents and antioxidant activity in tissues and/or peels [82].The in vitro antioxidant activity of Citrus sinensis peel extracts from different solvents were investigated. Among the different solvent extracts methonolic extract exhibited the highest in vitro scavenging activity followed by other solvent extracts which includes ethanolic, hexane, benzene, ethyl acetate, and chloroform with $\mathrm{IC}_{50}$ values $65.44,120,138.45,151.34,170.34,185.35$ with $55.6 \%$ inhibitory concentration for ascorbic acid [83]. Hesperidin was extracted from the peel of Citrus sinensis, and its antioxidant capacity was evaluated. Hesperidin was found to be moderately active as an antioxidant agent; its capacity reached $36 \%$ [84]. The antioxidant, protective and bioavailability of Citrus sinensis juice (poly)phenols were studied by monitoring urinary flavanone metabolites and ring fission catabolites produced by the action of the colonic microbiota. Twelve volunteers [ 6 men and 6 women; body mass index (in $\mathrm{kg} / \mathrm{m}^{2}$ ): 23.9-37.2] consumed a low (poly)phenol diet for 2 days before first drinking $250 \mathrm{ml}$ pulp-enriched orange juice, which contained $584 \mu \mathrm{mol}$ (poly)phenols of which $537 \mu \mathrm{mol}$ were flavanones. Urine collected for a 24 -h period was analyzed qualitatively and quantitatively. A total of 14 metabolites were identified and quantified in urine after orange juice intake. 
Hesperetin-O-glucuronides, naringenin-O-glucuronides, and hesperetin-3'-O-sulfate were the main metabolites. The overall urinary excretion of flavanone metabolites corresponded to $16 \%$ of the intake of $584 \mu \mathrm{mol}$ (poly)phenols. This bioavailability could be explain the antioxidant and protective effect of orange juice (poly)phenols [85].

\section{Clerodendrum inerme}

All Clerodendrum species showed antioxidant potential by all the antioxidant assays tested (DPPH Assay, Reducing Power Assay and Total Antioxidant Activity). For DPPH assay maximum antioxidant activity, Reducing Power Assay and Total Antioxidant Activity, $C$. inerme showed nearly the maximum activity among Clerodendrum species [86-87].Study of methanolic extract of leaves of $C$. inerme showed free radical scavenging activity increasing with concentration, with maximum activity at $2500 \mathrm{mg} / \mathrm{ml}$. This antioxidant activity may be attributed to phenolic compounds [87-88].The total methanolic extract (TME) of the aerial parts, and compound -hydroxy-6,7,4'-trimethoxy flavone showed scavenging activity with maximum inhibition of $61.84 \%$ for TME $(100 \mu \mathrm{g} / \mathrm{ml})$ and $37.19 \%$ for -hydroxy-6,7,4'-trimethoxy flavone $(20 \mu \mathrm{M})$, using DPPH assay $[87,89]$.

\section{Clitoria ternatea}

The different solvent extracts of Clitoria ternatea leaf were assessed for their in vitro free radical scavenging potential by 1,1-diphenyl-2-picryl-hydrazyl (DPPH) radical scavenging assay. All extracts exhibited potent in vitro free radical scavenging activity that increased with extract concentrations. The methanol extract was found to be the most potent, followed by the chloroform and petroleum ether extracts [90-91].

Petrolem ether, chloroform and methanol extracts of roots of blue and white flowered varieties of Clitoria ternatea were studied for their antioxidant potential. DPPH free radical scavenging assay, reducing power assay, hydroxyl radical scavenging assay were used for evaluation of antioxidant potential. Petrolem ether, chloroform and methanol extracts of roots of blue and white flowered varieties of Clitoria ternatea (CT) significantly inhibited the DPPH free radical at concentrations ranging from 50-600 $\mathrm{mu} \mathrm{g} / \mathrm{ml}$. Petroleum ether, chloroform and methanol extracts of roots of blue flowered variety of CT showed highest inhibition (49.11, 35.42 and $70.67 \%$ at $600 \mathrm{mug} / \mathrm{ml}$ ), respectively. Petroleum ether, chloroform and methanol extracts of roots of white flowered variety of (CT) showed highest inhibition $(54.48,39.21$ and $78.13 \%$ at $600 \mathrm{mu} \mathrm{g} / \mathrm{ml}$ ), respectively. Methanol extracts of blue and white flowered varieties of CT showed a very powerful antioxidant activity in DPPH radical-scavenging assay. Methanol extracts of CT also showed significant reductive ability as well as hydroxyl radical scavenging activity. Methanol extract of white flowered variety of CT showed more significant antioxidant activity as compared to blue flowered variety of CT. All the concentrations of methanol extract of CT (MECT) showed antioxidant activity when compared to control $(p<0.001)$ [91-93].The antioxidant activity of the leaves as well as blue and white flowers of Clitoria ternatea was investigated. They exhibited significant antioxidant activity and the sample from the blue flower bearing plant showed better scavenging activity [94].

The antioxidant activity and protective ability of Clitoria ternatea flower petal extract (CTE) was investigated. CTE showed antioxidant activity as measured by oxygen radical absorbance capacity (ORAC) method and 2,2-diphenyl-1-picrylhydrazyl (DPPH) radical scavenging assay. CTE $(400 \mu \mathrm{g} / \mathrm{ml})$ remarkably protected erythrocytes against AAPH-induced hemolysis at $4 \mathrm{~h}$ of incubation. Moreover, CTE $(400 \mu \mathrm{g} / \mathrm{ml})$ reduced membrane lipid peroxidation and protein carbonyl group formation and prevented the reduction of glutathione concentration in AAPH-induced oxidation of erythrocytes. The AAPH-induced morphological alteration of erythrocytes from a smooth discoid to an echinocytic form was effectively protected by CTE [95]. The antioxidant effects and apoptotic study of the leaves of Clitoria ternatea was studied using the yeast cell. The yeast cells were isolated from the sugar factory effluents and the yeast cell DNA was isolated. The leaves extract from different solvents were tested for their scavenging activity against the stable free radical DPPH ( 2 , 2'-diphenyl-1-picryl hydrazyl) in dot plot rapid screening assay method and quantified using a spectrophotometric assay method. Oxidative damage was induced in vitro by treating yeast DNA and analyse the effects of the leaf extracts. Genomic DNA samples were isolated from YBD broth culture. DPPH scavenging activity was highly elicited by the methanol extract of Clitoria ternatea. The Clitoria ternatea leaf extracts treatment effectively decreased the extent of DNA damage [96].

The potential antioxidant activity of Clitoria ternatea extracts and an extract containing eye gel formulation was investigated. Aqueous extracts were shown to have stronger antioxidant activity (as measured by DPPH scavenging activity) than ethanol extracts $\left(\mathrm{IC}_{50}\right.$ values were $1 \mathrm{mg} / \mathrm{ml}$ and $4 \mathrm{mg} / \mathrm{ml}$, respectively). Aqueous extracts incorporated into an eye gel formulation were also shown to retain this activity, however, it was significantly less than a commercial antiwrinkle cream included for comparison. The total phenolic content was $1.9 \mathrm{mg} / \mathrm{g}$ extract as gallic acid equivalents [97].

The antioxidant property of methanolic extract (ME) of Clitoria ternatea leaf was investigated by employing an in vitro antioxidant assay. The hepatoprotective effect against paracetamol-induced liver toxicity in mice of ME of Clitoria ternatea leaf was also studied. Activity was measured by monitoring the levels of 
aspartate aminotransferase, alanine aminotransferase and billirubin along with histopathological analysis. The antioxidant activity of Clitoria ternatea leaf extract was $67.85 \%$ at a concentration of $1 \mathrm{mg} / \mathrm{ml}$ and was also concentration dependant, with an $\mathrm{IC}_{50}$ value of $420 \mu \mathrm{g} / \mathrm{ml}$. The results of the paracetamol-induced liver toxicity experiments showed that mice treated with the ME of Clitoria ternatea leaf $(200 \mathrm{mg} / \mathrm{kg})$ showed a significant decrease in ALT, AST, and bilirubin levels, which were all elevated in the paracetamol group ( $\mathrm{p}<0.01$ ). Clitoria ternatea leaf extract therapy also showed a protective effects against histopathological alterations [98].

\section{Colchicum balansae}

Methanol extracts of Colchicum balansae were investigated for antioxidant effect at $2000 \mu \mathrm{g} / \mathrm{ml}$ by 2,2-diphenyl-1-picrylhydrazyl (DPPH) radical scavenging activity. Methanol extracts of Colchicum balansae displayed low effect in DPPH, below 40\% [99].The antioxidant properties of Colchicum balansae Planchon (CB) were investigated. The solvent extracts were prepared from CB tubers and leaves. Free radical scavenging activities were determined. Result of this study show that leaves extracts of CB exhibited higher antioxidant activity than tuber extracts with all types of solvent. The highest antioxidant activity efficiency was determined in extract leaf-ethanol (64\%) and the least efficiency in extract tuber-benzine (14.5\%). All extracts of CB tubers and leaves have effective free radical scavenging and reducing power. The highest free radical scavenging activity was determined in extract leaf-benzine $(68.35 \%)$, followed by acetone $(61.23 \%)$, methanol $(58.67 \%)$ and ethanol extracts $(54.74 \%)$ respectively. The highest radical scavenging activity was determined in extract tuber-benzine $(61.28 \%)$, and the least efficiency in extract tuber-ethanol $(20.48 \%)$. In addition, all extracts of $\mathrm{CB}$ tubers and leaves were determined as pyrocatechol equivalents [100].

\section{Convolvulus arvensis}

The antioxidant activity of the Convolvulus arvensis ethanol extract has been evaluated by different ways. The antioxidant activity of the extract assessed by (ABTS) radical cation, the oxygen radical absorbance capacity (ORAC) and the ferric reducing antioxidant power (FRAP) was $1.62 \mathrm{mmol}$ Trolox equivalents (TE)/g DW, $1.71 \mathrm{mmol} \mathrm{TE} / \mathrm{g} \mathrm{DW}$ and $2.11 \mathrm{mmol} \mathrm{TE} / \mathrm{g}$ DW, respectively. A preliminary study of gelatine based film containing Convolvulus arvensis showed a strong antioxidant effect in preventing the degradation of lipid in muscle food. Accordingly, the results indicated that Convolvulus arvensis extract can be used as a natural food antioxidant [101].

Aerial parts of Convolvulus arvensis were subjected to extraction and further fractionation to obtain antioxidant rich fraction. Different concentrations of methanolic extract and its ethyl acetate fraction were subjected to antioxidant assay by DPPH method, nitric oxide scavenging activity and reducing power assay. The fractions showed dose dependent free radical scavenging property in all the models. IC ${ }_{50}$ values for methanolic extract and its ethyl acetate fraction were found to be $131.03 \pm 2.46$ and $43.21 \pm 4.45 \mu \mathrm{g} / \mathrm{ml}$ respectively in comparison to $6.537 \pm 0.235$ and $5.437 \pm 0.206 \mu \mathrm{g} / \mathrm{ml}$ for $\mathrm{L}$-ascorbic acid and rutin respectively in DPPH model. In nitric oxide scavenging activity the $\mathrm{IC}_{50}$ values were found to be $130.12 \pm 2.46$ and $57.5 \pm 4.45 \mu \mathrm{g} / \mathrm{ml}$ for methanolic extract and its ethyl acetate fraction, and $21.06 \pm 0.953$ and $29.93 \pm 0.324$ $\mu \mathrm{g} / \mathrm{ml}$ for L-ascorbic acid and rutin respectively. The fractions showed good reducing power with increasing concentration. However, the ethyl acetate fraction showed a good reducing power and better free radical scavenging activity as compared to methanolic extract, its antioxidant potential was comparable to standards [102].

Acidic ethyl acetate fraction was prepared from the leaves of Convolvulus arvensis, antioxidant activity and reducing power were evaluated for this fraction. The fraction exhibited strong antioxidant activity measured by 1,1-diphenyl-2-picrylhydrazyl (DPPH) radical scavenging method and its $\mathrm{IC}_{50}$ value was $66.9 \pm 0.1$ $\mathrm{pg} / \mathrm{ml}$. Furthermore, it possessed strong reducing power and inhibited the oxidation of P-carotene [103].

\section{Corchorus aestuans}

The antioxidant potency of the Corchorus aestuans leaves crude methanol and its fractionated extracts (hexane, ethyl acetate and water) were investigated, employing three different established in vitro testing systems, scavenging activity on 1,1-diphenyl-2-picrylhydrazyl (DPPH) radicals, reducing power assay and $\beta$ carotene method. The data obtained in these testing systems clearly establish the antioxidant potency of Corchorus aestuans [104].

The antioxidant activity of the flavonoids (quercetin and quercetin 3-o-galactoside) isolated from the aerial parts of Corchorus aestuans was tested by two in vitro testing methods, scavenging activity on 1, 1diphenyl-2-picrylhydrazyl (DPPH) radicals and hydroxyl radical scavenging activity by EDTA. The data obtained in these testing systems clearly established that Corchorus aestuans possessed antioxidant potential. The scavenging activity ( $\%$ inhibition of $50 \mu \mathrm{g} / \mathrm{ml}$ ) of isolated flavonoids quercetin 3-o-galactoside, quercetin and ascorbic acid on the DPPH radical decreased in the order: Ascorbic acid > Quercetin > Quercetin 3-ogalactoside was of $67.55 \pm 0.10,28.19 \pm 0.22$ and $24.64 \pm 0.14(\mathrm{P}<0.0001)$ at the concentration $50 \mu \mathrm{g} / \mathrm{ml}$ respectively. The concentration of quercetin 3-o-galactoside caused $50 \%$ inhibition of the free radical $\left(\mathrm{EC}_{50}\right)$ was $87 \mu \mathrm{g} / \mathrm{ml}$ and those of quercetin and ascorbic acid were $65 \mu \mathrm{g} / \mathrm{ml}$ and $25 \mu \mathrm{g} / \mathrm{ml}$ [105]. 
The free radical scavenging properties of some plants found in Malaysia such as, Corchorus capsularis was studied. The air-dried leaves of the plant $(20 \mathrm{~g})$ were soaked in distilled water $(1: 20$; w/v) for $72 \mathrm{~h}$ at room temperature. The collected supernatants were tested for the free radical scavenging activity against the DPPH and superoxide anion radical scavenging assays. The extract showed remarkable antioxidant activity in both assays with the percentage of inhibition nearly $90 \%$ [106-107].

The crude methanolic extract of Corchorus capsularis (leaves) and its fructions $(5-25 \mu \mathrm{g} / \mu \mathrm{l})$, were tested for the free radical scavenging activity against the DPPH and superoxide anion radical scavenging assays. Extracts were found to show remarkable antioxidant activity in both assays with the percentage of inhibition. Hexan extract caused 65.44-97.43\% inhibition and appeared the most potent antioxidant extract, followed by butanol, methanol and ethyl acetate extracts [107-108].

Cordia myxa

The total phenol contents of Cordia myxa fruits were $373.91 \pm 13.93 \mathrm{mg} / 100 \mathrm{~g}$ dry weight, and antioxidant activity $\left(\mathrm{IC}_{50}\right)$ was $132.53 \pm 5.75 \mu \mathrm{g} / \mathrm{ml}$ [109-110].Plant extracts were evaluated for their phenolic content and antioxidant activity. Phenolic content was measured using Folin-Ciocalteu reagent and was calculated as gallic acid equivalents. Antiradical activity of Cordia myxa extracts was measured by DPPH assay and was compared to ascorbic acid. One milligram of the crude extract was found to be equivalent to $15 \mu \mathrm{g}$ of ascorbic acid [110-111].

However on another study, DPPH assay was used to measure antiradical activity of the extracts and it was compared with ascorbic acid. Its antiradical activity was measured as $16.34 \pm 0.81$ that was calculated as $10.0 \pm 1.24$ ascorbic acid equivalent[112].

Performance of antioxidants is improved by incorporating them into polymer matrix such as polysaccharides based edible coatings. Gum cordia, an anionic polysaccharide extracted from the fruits of Cordia myxa could be used as carrier of antioxidants by virtue of its strong adhering and emulsifying properties. The potential of gumcordia as carrier of antioxidants when applied as edible coating on peanuts was investigated. Gum Cordia was compared with carboxymethyl cellulose (CMC) in delivering of antioxidants: butylated hydroxyanisole (BHA), butylated hydroxytoluene (BHT) and ascorbic acid (AA). Coated and uncoated peanuts were stored at $35^{\circ} \mathrm{C}$ for 126 days and coating carrier effectiveness was measured by following lipid oxidation using chemical parameters (peroxide value and thiobarbituric acid reactive species) and sensory evaluation (oxidized flavor). Significant differences $(p<0.05)$ between coated and uncoated samples were observed. Gum cordia was found better than CMC to deliver the antioxidants. Gum cordia based coating in combination with BHA/BHT exhibited highest protection (290\% higher shelf life than control) based on peroxide value $\left(40\right.$ meq. $\mathrm{O}_{2} / \mathrm{kg}$ ) followed by gum codia plus BHT $(244 \%)$, gum cordia plus BHA (232\%), CMC plus BHA/BHT (184 \%), CMC plus BHA (139\%), CMC plus BHT (119\%), gum cordia plus AA (96\%) and CMC plus AA (46\%) [110,113].

\section{Coriandrum sativum}

Coriandrum sativum has a very effective antioxidant profile showing 2,2-diphenyl-1-picrylhydrazyl (DPPH) radical scavenging activity, lipoxygenase inhibition, phospholipid peroxidation inhibition, iron chelating activity, hydroxyl radical scavenging activity, superoxide dismutation, glutathione reduction and antilipid peroxidation due to its high total phenolic content[114-117].

The fresh juice exhibited high antioxidant activities, evidenced by its ability to scavenge hydroxyl- and superoxide-radicals, high reducing power, and protection against biological macromolecular oxidative damage and by increasing the level of glutathione [118].

Among the leaf essential oil and leaf petroleum ether, chloroform, ethyl acetate and methanol extracts of Coriandrum sativum studied, methanol extract and leaf essential oil showed potent scavenging activity on 1, 1-diphenyl-2-picrylhydrazyl (DPPH) radical [119]. The in vitro antioxidant potential of aqueous leaf extracts of Coriandrum sativum leaves was determined qualitatively. Enzymatic antioxidant analysis in the extract of Coriandrum sativum: Catalase $\left(\mu /\right.$ moles of $\mathrm{H}_{2} \mathrm{O}_{2}$ decomposed $/ \mathrm{min} / \mathrm{g}$ protein, 1 unit $=\mu / \mathrm{moles}$ of $\mathrm{H}_{2} \mathrm{O}_{2}$ decomposed $/ \mathrm{min} / \mathrm{g}$ protein $)=3.135$; peroxidase $(\mathrm{Unit} / \mathrm{mg}$ protein, 1 unit $=\mathrm{mg}$ of $\mathrm{GSH}$ utilized $/ \mathrm{min})=$ $2.508 \times 10^{3}$; ascorbate oxidase $(\mu \mathrm{mole} / \mathrm{ml}, 1$ unit $=0.01$ O.D change $/ \mathrm{min})=100.262[120]$.

The amount of the total phenolic contents (TPC) in the aqueous extract of Sudanese Coriandrum sativum was $1654 \pm 3.4 \mathrm{mg}$ GAE/L. The results of the in vitro antioxidant activity by $\beta$-carotene/linoleic acid assay, showed that Coriandrum sativum aqueous extract had strong antioxidant activity $(84.6 \%$ at $400 \mathrm{ug} / \mathrm{ml})$, when compared with the standard reference Tert-butyl hydroquinone (TBHQ) (99.5\% at the same concentrations). The aqueous extract showed strong DPPH free-radical scavenging activity $(88.5 \%$ at $400 \mathrm{ug} / \mathrm{ml})$, compared with the standard reference (TBHQ) (99.73\% at the same concentration) [121].

The pre-feeding of rats with coriander seed powder (CSP) at $10 \%$ level was found to reduce the experimentallyinduced (HCH-induced) rise in conjugated dienes, hydroperoxide and malondialdehyde (MDA) contents in the liver [122]. 
The antiperoxidative effect of coriander seeds (Coriandrum sativum) was studied in rats administered high fat diet. Significant decrease in the levels of lipid peroxides, free fatty acids and glutathione were observed when compared to control group whereas the activity of antioxidant enzymes was increase [123].Phenolic content and antioxidant activity were evaluated in the coriander leaves and seeds. The results revealed that serum alanine aminotransferase (ALT), aspartate aminotransferase (AST) and alkaline phosphatase (ALP) activities were significantly increased in thioacetamide (TAA)-induced hepatotoxicity groups compared to the normal control. Oxidative stress was manifested by a significant rise in nitric oxide (NO), thiobarbituric acid reactive substance (TBARS) levels and myloperoxidase (MPO) activities in the liver tissues, in induction group compared with the control. Rats fed with coriander leaves and seeds showed a decrease in the serum ALT, AST and ALP activities and in the liver NO and TBARS levels as compared to the induction group. Histopathological study revealed that coriander feeding attenuated TAA-induced hepatotoxicity in rats [124]. The production of antioxidants in vegetative parts (leaves and stems) of in vivo and in vitro grown coriander samples was studied and compared. The antioxidant activity was evaluated by radical scavenging activity, reducing power and lipid peroxidation inhibition. The in vivo sample showed the highest antioxidant activity, which appeared proportional to levels of hydrophilic compounds. Otherwise, in vitro samples, gave the highest concentration of lipophilic compounds but a different profile when compared to the in vivo sample [125].

The antioxidant and free radical scavenging property of seeds were evaluated in addition to investigation whether the administration of seeds affected the oxidative stress in the kidney of streptozotocininduced diabetic rats. Incorporation of seed powder in the diet led to marked lowering of blood glucose and a rise in the levels of insulin in diabetic rats. A parallel beneficial effect was observed on oxidant -antioxidant balance in the kidney. Addition of coriander seed powder not only inhibited the process of peroxidative damage but also significantly reactivated the antioxidant enzymes and antioxidant levels in diabetic rats. The seeds also showed scavenging activity against superoxides and hydroxyl radicals in a concentration-dependent manner. Maximum free radical-scavenging action and free radical reducing power of coriander seed was observed at a concentration of 50 microg GAE. Islet histology structures showed degeneration of pancreatic islets in diabetic rats which was also reduced in diabetic rats treated with seed powder [126].

The hydroalcohol extract of Coriandrum sativum leaves at the dose of $1 \mathrm{mg} / \mathrm{ml}$ was subjected to a series of in vitro assays (2, 2'- diphenyl-1-picrylhydrazyl, lipid peroxidation by thiobarbituric acid, reducing power and nitric oxide (NO) radical scavenging) in order to study its antioxidant efficacy. The amount of flavonoids in $70 \%$ ethanol extract was found to be $44.5 \mu \mathrm{g}$ and that of the total phenols was $133.74 \mu \mathrm{g}$ gallic acid equivalents per mg extract. The extracts of the leaves showed metal chelating power, with $\mathrm{IC}_{50}$ value of $368.12 \mu \mathrm{g} / \mathrm{ml}$, whereas that of standard EDTA was $26.7 \mu \mathrm{g} / \mathrm{ml}$. The $\mathrm{IC}_{50}$ values for 2, 2'-azino-bis (3ethylbenzothiazoline-6-sulphonic acid radical scavenging was $222 \mu \mathrm{g} / \mathrm{ml}$, whereas that of standard ascorbic acid was $22.6 \mu \mathrm{g} / \mathrm{ml}$. The $\mathrm{NO}$ scavenging activity of the extract of the leaves showed $\mathrm{IC}_{50}$ value of $815.6 \mu \mathrm{g} / \mathrm{ml}$; at the same time the standard BHA had $49.1 \mu \mathrm{g} / \mathrm{ml}$. All the plant extracts provided DNA damage protection; however, the protection provided at the dose of $8 \mu \mathrm{g} / \mathrm{ml}$ was comparable to that of standard gallic acid. The Coriandrum sativum leaf extract was able to prevent in vitro lipid peroxidation with $\mathrm{IC}_{50}$ value of $589.6 \mu \mathrm{g} / \mathrm{ml}$, whereas that of standard BHA was $16.3 \mu \mathrm{g} / \mathrm{ml}$. The results also showed significant ferric reducing power indicating the hydrogen donating ability of the extract [127].

\section{Coronilla scorpioides}

Investigation of the antioxidant potentials of 110 selected Egyptian plants revealed that the most potent plants was Coronilla scorpioides with calculated antioxidant values of $454.80 \pm 4.83 \%$ for methanol extracts [128].

\section{Cotoneaster racemiflora}

Racemiside, scopoletin, 7,8-dimethoxy-6-hydroxycoumarin, 3,3',4'-tri-O-methylellagic acid, and cereotagloperoxide isolated from the ethyl acetate-soluble fraction of Cotoneaster racemiflora, showed profound antioxidative activities in the DPPH assay [129].Free radical scavenging activity measured by 1,1diphenyl-2-picryl-hydrazil (DPPH) showed that methyl 3,4-dihydroxy-5-methoxybenzoate isolated from the plant possessed significant antioxidant $\left(\mathrm{IC}_{50}\right.$ : $\left.9.7 \pm 0.12 \mu \mathrm{m}\right)$. The spectrophotometric method showed that the same compound exerted lipoxygenase inhibitory activities $\left(\mathrm{IC}_{50}\right.$ : 19.5 $\left.\pm 0.07 \mu \mathrm{m}\right)$ [130].Antioxidant capacities of ethyl acetate, methanol and water extracts of the plant were evaluated by free radical scavenging assay (DPPH, ABTS and $\mathrm{O}_{2}$ ), reducing power, phosphomolybdenum, $\beta$-carotene/linoleic acid bleaching and metal chelating assays. The highest DPPH and $\mathrm{O}_{2}$ scavenging activities were exerted by water extract of the plant, followed by the methanol extract. However, the greatest ABTS inhibition was caused by the methanol extract $\left(\mathrm{IC}_{50}: 0.020\right.$ $\mathrm{mg} / \mathrm{ml}$ ) closely followed by the water extract $\left(\mathrm{IC}_{50}: 0.023 \mathrm{mg} / \mathrm{ml}\right)$. There were no significant differences in free radical scavenging activities between methanol and water extracts [131].

\section{Cressa cretica}

n-Butanol extracts of nine medicinal plants, Cressa cretica, Ziziphus spinachrist, Acacia tortilis, Tephrosia haussknechti, Aristolochiae bracteolata, Citrullus colocynthis, Teucrium mascatense, Rhazya stricta and Nerium oleander, were screened for their antioxidant activity using phosphomolybdenum complex assays and 
their radical scavenging activity using DPPH assays. Cressa cretica showed high level of DPPH scavenging activities $87.7 \%$ [132-133]. The free radical scavenging activity of Cressa cretica was studied on in vitro antioxidant models. The antioxidant activity was evaluated by determining the activity of hydrogen peroxide $\left(\mathrm{H}_{2} \mathrm{O}_{2}\right)$ radicals scavenging and 1,1-diphenyl-2-picryl hydrazyl (DPPH) assay. In all these models, a significant correlation existed between concentrations of the extract and percentage inhibition of free radicals [133-134].

The methanolic (Fr-Me) and ethyl acetate fraction (Fr-Et) obtained from the aerial parts of Cressa cretica significantly increased plasma superoxide dismutase, catalase, glutathione and glutathione peroxidase activities. On the other hand, the malonaldehyde (as a measure of lipid peroxidation) level was significantly decreased in comparison with the control group [135].

\section{Crocus sativus}

The extract of Crocus sativus showed high superoxide dismutase activity by cytochrome c reduction, nitro blue tetrazolium reduction, and pyrogallol autoxidation methods [136-137].

Antioxidant activity of saffron was tested by Folin-Ciocalteu $(\mathrm{F}-\mathrm{C})$ reagent and various free radical species produced in cell-free or cell model systems. Oregano and turmeric methanol extracts were used as reference antioxidants. In the human monocyte system, saffron extracts or free crocetin were found to reduce ROS production as effectively as the phenolic antioxidants [137-138].

The antioxidant activity of saffron stigmas was evaluated after extraction with different solvents. Results showed that saffron stigma possessed antioxidant activity. The free radical scavenging and ferric reducing power activities were higher for the methanolic extract of saffron stigma at a concentration of 300 $\mu \mathrm{g} / \mathrm{ml}$, with values of $68.2 \%$ and $78.9 \%$, respectively, as compared to the corresponding boiling water and ethanolic extracts, but the activities were lower than those of antioxidant standards such as BHT and $\alpha$ tocopherol [139].

The radical scavenging activities of Crocus sativus petals, stamens and entire flowers, which were waste products in the production of the saffron, were determined by employing ABTS radical scavenging method. The high variety of glycosylated flavonoids found in the metabolic profiles and the radical scavenging activities, gave value to Crocus sativus petals, stamens and entire flowers as antioxidant therapy [140].

The antioxidant activity of the extract of Crocus sativus, and some of its bioactive constituents (crocin, safranal) was studied. Methanol extract of Crocus sativus exhibited high antioxidant activity. In trying to approximate a structure-activity relationship, two bioactive constituents of saffron extract were tested, namely crocin and safranal. Crocin showed high radical scavenging activity (50\% and $65 \%$ for 500 and $1,000 \mathrm{ppm}$ solution in methanol, respectively), followed by safranal ( $34 \%$ for $500 \mathrm{ppm}$ solution). All the tested samples showed high radical scavenging activity, probably due to the ability to donate a hydrogen atom to the DPPH radical [141].

The antioxidant activity of methanolic extract of Crocus sativus flowers was evaluated by total phenolic contents (TPC), 1,1-diphenyl-2-picrylhydrazyl (DPPH) radical scavenging activity, 2,2-azino-bis-(3ethylbenzothiazoline-6-sulfonic acid) radical scavenging activity (ABTS) and the reducing power. The results showed that TPC was $86.65 \mathrm{mg} / \mathrm{g}$ gallic acid equivalents, while DPPH and ABTS for $1 \mathrm{mg} / \mathrm{ml}$ concentration were 92.41 and 86.87 , respectively. In the reducing power experiment, the $\mathrm{IC}_{50}$ value was 231.75 [142].

The antioxidants crocin and kaempferol were purified by flash column chromatography, and identified by thin layer chromatography (TLC), HPLC-DAD, infrared (IR), and nuclear magnetic resonance $\left({ }^{1} \mathrm{H} \&{ }^{13} \mathrm{C} N \mathrm{NR}\right)$ spectroscopy. The antioxidant activity was determined with the ABTS and DPPH tests. The antioxidant activities were mainly attributed to carotenoid and flavonoid compounds, notably glycosides of crocin and kaempferol. Crocin and kaempferol in dried petals were $0.6 \%$ and 12.6 (w/w), respectively. Petals of Crocus sativus have commercial potential as a source for kaempferol and crocetin glycosides, natural compounds with antioxidant activity that were considered to be the active ingredients in saffron-based herbal medicine [143].

The effect of aqueous saffron extract (Crocus sativus) and its active constituent, crocin on oxidative stress was evaluated following renal ischemia-reperfusion injury (IRI) in rats. The left kidney was exposed to warm ischemia for $60 \mathrm{~min}$ followed by reperfusion for $90 \mathrm{~min}$. The macerated aqueous extract of saffron (with doses of 5,20 and $80 \mathrm{mg} / \mathrm{kg}$, ip) and crocin (with doses of 50, 200 and $400 \mathrm{mg} / \mathrm{kg}$, ip) were administrated prior to induction of ischemia. Normal saline $(10 \mathrm{ml} / \mathrm{kg}$, ip) was injected to control group and a sham group that did not have ischemia-reperfusion. Ischemia-reperfusion (IR) caused a significant increase in thiobarbituric acid reactive species (TBARS) levels $(\mathrm{p}<0.001)$ and decrement in both antioxidant power (FRAP value) $(\mathrm{p}<0.05)$ and total thiol concentration $(\mathrm{p}<0.001)$ in kidney homogenate samples. In crocin pretreated groups, a reduction in TBARS levels (from $85.8 \pm 5.4$ to $20.9 \pm 1.5 \mathrm{nmol} / \mathrm{g}$ tissue, $\mathrm{p}<0.001 ; 400 \mathrm{mg} / \mathrm{kg}$ ) and elevation in antioxidant power (FRAP value) (from $3.05 \pm 0.16$ to $4.15 \pm 0.16 \mathrm{micromol} / \mathrm{g}$ tissue, $\mathrm{p}<0.001 ; 400 \mathrm{mg} / \mathrm{kg}$ ) and total thiol concentrations (from $0.38 \pm 0.03$ to $0.62 \pm 0.03 \mathrm{mM}, \mathrm{p}<0.001 ; 200 \mathrm{mg} / \mathrm{kg}$ ), as compared with control group, were recorded. The aqueous extract also reduced lipid peroxidation products (from $85.8 \pm 5.4$ to $15.9 \pm 2.6$ $\mathrm{nmol} / \mathrm{g}$ tissue, $\mathrm{p}<0.001 ; 80 \mathrm{mg} / \mathrm{kg}$ ) and increased antioxidant power (from $2.98 \pm 0.11$ to $5.97 \pm 0.56$ micromol/g tissue, $\mathrm{p}<0.001 ; 80 \mathrm{mg} / \mathrm{kg}$ ) in ischemia-reperfusion injured rat kidneys [144]. 
Protocatechuic acid, kaempferol, and kaempferol 7-O-beta-d-glucopyranoside isolated from Crocus sativus were more effective in scavenging alpha, alpha-diphenyl-beta-picrylhydrazyl (DPPH) radicals than alphatocopherol [145].

\section{Crotalaria juncea}

Antioxidant activity of Crotalaria juncea extracts were studied in goat liver lipid peroxidation, linoleic acid emulsion, $\alpha$-amylase and lipase inhibitory activity. All the extracts had shown antioxidant property, $\alpha$-amylase, and lipase inhibitory properties. Aqueous extract was found to show maximum antioxidant activity on goat liver. Antilipid peroxidation and antioxidant activity were determined as $66.94 \pm 0.616 \%(\mathrm{p}<0.01)$ and $59.54 \pm 0.2 \%(p<0.01)$, respectively. Maximum $\alpha$-amylase and lipase inhibitory activities of $71.42 \pm 1.37 \%$ $(\mathrm{p}<0.01)$ and $57.14 \pm 2.74 \%(\mathrm{p}<0.01)$, respectively, were exhibited by macerated methanol extract [146-147].

The antioxidant activity of Crotalaria juncea seed oil (CJSPE) was evaluated by in vitro assay methods (2,2Diphenyl-1-picrylhydrazy 1 (DPPH), hydroxyl and superoxide radical scavenging activity) of CJSPE; its antioxidant activity was found to be concentration dependent and $\mathrm{IC}_{50}$ values were 132.31, 286.409 and 31.254 $\mathrm{g} / \mathrm{ml}$ by the tree tests, respectively. Moreover, CJSPE has displayed dose dependant, significant inhibition of NO production in the isolated rat peritoneal macrophages [147-148].

\section{Cuminum cyminum}

The antioxidant capacity of cumin by ABTS and DPPH assays was3.26 \pm 0.29 and $2.16 \pm 0.06$ (mmol TE/g DW) respectively [149-150].

The antioxidant activity of cumin was studied. The oil showed higher antioxidant activity compared with that of BHT and BHA. The cumin essential oil exhibited a dose-dependent scavenging of DPPH radicals and 5.4 microg of the oil was sufficient to scavenge $50 \%$ of DPPH radicals/ml [150-151].

Antioxidant activity of essential oils was evaluated by DPPH radical scavenging assay, radical inhibition of Cuminum cyminum essential oils was $83.59 \%$, the scavenging activities of the essential oil was increased with the increased of the essential oil concentrations [152].

It appeared that the full ripe seeds were richer on polyphenols and condensed tannin than unripe ones, and consequently exhibited higher antioxidant activities. However, the unripe seeds had a higher total flavonoid content compared to those of half ripe and full ripe ones. The comparison of two extraction methods, the soxhlet extracts contained the greatest amount of polyphenols and flavonoids, while maceration samples exhibited higher antiradical and bleaching power assay. Total phenolic contents and $\mathrm{IC}_{50}$ values in cumin seed during their maturation allowed to conclude that antioxidant activity does not depend only on the high content of total phenolics but also on the phenolic composition [153].

The antioxidant activities of $\beta$-pinene, p-cymene, $\gamma$-terpinene, cuminaldehyde and cumin oils (cumin oleoresin/COR, cumin essential oil/CEO, distillation residue/DR and distillate condensed from cold trap/CT) were investigated in the present study. $\mathrm{IC}_{50}$ values and kinetics rates were used to evaluate the efficiency of tested samples in scavenging the alkyl peroxyl radical generated in the $\beta$-carotene-linoleic acid system and the 2,2-diphenyl-1-picrylhydrazyl radical (DPPH). In kinetic approach, antioxidant activities of tested samples were expressed as the rate of $\beta$-carotene bleaching $(\mathrm{R}(\beta$-carotene $))$ and DPPH scavenging $(\mathrm{R}(\mathrm{DPPH}))$, respectively. The order of antioxidant activities of cumin oils was $\mathrm{DR}=\mathrm{COR}>\mathrm{CEO}>\mathrm{CT} . \quad \gamma$-Terpinene exhibited lower $\mathrm{R}\left(\beta\right.$-carotene) value and the lowest $\mathrm{IC}_{50}(\beta$-carotene $)$ value, which indicated the stronger response in alkyl peroxyl radical scavenging. The R2(DPPH) values for $\gamma$-terpinene, followed by DR and COR, showed high response in scavenging DPPH, with IC50 values of $22.73,6.72,8.53 \mathrm{mg} / \mathrm{ml}$, respectively. $\gamma$-terpinene appeared the most efficient antioxidant compounds in cumin oils [154].

Thiobarbituric acid reactive substances (TBARS) assay was used to evaluate the lipid peroxidation of Cuminum cyminum extract. The extract also produced significant lipid peroxidation inhibition in comparison with known antioxidant ascorbic acid in both rat liver and brain [155].

The antioxidant activities of Cuminum cyminum essential oils and acetone extracts obtained from the three organs were assessed using four tests [1,1-diphenyl-2-picrylhydrazyl (DPPH), $\beta$-carotene/linoleic acid, reducing power, and chelating power assays]. The acetone extract of flowers was strongly effective as a DPPH radical scavenger, lipid peroxidation inhibitor, and reducing agent, with $\mathrm{IC}_{50}$ values of 4,32 , and $8 \mu \mathrm{g} / \mathrm{ml}$, respectively. Moreover, the acetone extract of stems and leaves showed the highest chelating power. However, the essential oils exhibited moderate activities in the different tests [156].

Two complementary assays were used to assess the antioxidant activity of cumin and caraway methanolic and acetonic seed extracts: the DPPH free radical scavenging assay and the $\beta$-carotene bleaching assay. Both cumin and caraway seed extracts were able to neutralize free radicals over a period of $60 \mathrm{~min}$ in the DPPH assay, with most of the neutralization occurring quickly within the first 30s. The steady state was reached within 10min, and it appeared that the acetonic extracts of both seeds had less antioxidant activity than the methalonic extracts. The methanolic and acetonic extracts of cumin showed slightly higher neutralization ability than the respective extracts from caraway within three minutes of assay initiation (57.0 and $52.4 \%$ for cumin and 44.7 and $39.5 \%$ for caraway [157]. 
The effect of Cuminum cyminum was investigated on alcohol and thermally oxidized oil induced hyperlipidaemia. The results showed increased activity of aspartate transaminase (AST), alkaline phosphatase (ALP) and gamma glutamyl transferase (GGT) and increased levels of cholesterol, triglycerides and phospholipids in the plasma of rats given alcohol, thermally oxidized oil and alcohol+ thermally oxidized oil when compared with the normal control group. The levels of tissue (liver and kidney) cholesterol and triglycerides were increased significantly in rats groups given alcohol, thermally oxidized oil and alcohol+ thermally oxidized oil when compared with the normal control rats. The levels were decreased when cumin was given along with alcohol and thermally oxidized oil. The level of phospholipids decreased significantly in the liver and kidney of groups given alcohol, thermally oxidized oil and alcohol+ thermally oridized oil when compared with the normal control rats. The level increased when cumin was administered along with alcohol and thermally oxidized oil. The activity of phospholipase A and C increased significantly in the liver of groups given alcohol, thermally oxidized oil and alcohol+ thermally oxidized oil when compared with the normal control rats, whereas the activity was decreased with the cumin treatment. The results indicate that cumin can decrease the lipid levels in alcohol and thermally oxidized oil induced hepatotoxicity [158].

\section{Cupressus sempervirens}

The chloroform and methanol leaf extracts of Cupressus sempervirens were tested for antioxidant activity using the DPPH assay. Antiradical activity of the chloroform extract $(50 \mu \mathrm{g} / \mathrm{ml})$ was $6 \%$, while that of methanol extract $(50 \mu \mathrm{g} / \mathrm{ml})$ was $65 \%$ [159-160].

The antioxidant activities of Cupressus sempervirens fresh leaves by nitric oxide scavenging assay was 1.17 (mg quercetin /g extract), by reducing power assay was 2.85 ( $\mathrm{mg}$ ascorbic acid/g extract), by metal chelating assay was 2.70 (mg EDTA/g extract) and by phospho molbdenum antioxidant assay was 16.5 (mg Ascorbic $\mathrm{acid} / \mathrm{g}$ extract) [160-161].

Antioxidant activity of the extracts of two varieties was determined using 2,2-diphenyl-1picrylhydrazyl (DPPH) and $N, N$-dimethyl-p-phenylendiamine (DMPD) radical scavenging activity, metalchelation capacity along with ferric- (FRAP) and phosphor-molibdenum reducing antioxidant power (PRAP) tests. Antioxidant activity of the extracts was screened at $2000 \mu \mathrm{g} / \mathrm{ml}$. In general, antioxidant activity of the extracts was observed to show a discrepancy according to the method used. For instance; the cone ethyl acetate extract of Cupressus sempervirens var. horizantalis displayed the highest DPPH radical scavenging activity $(87.53 \pm 0.17 \%)$, while only six of the extracts had ability to scavenge DMPD radical varying from $6.06 \pm 0.23$ to $30.34 \pm 0.69 \%$. In the FRAP assay, the cone acetone extract of Cupressus sempervirens var. horizantalis exhibited the highest absorbance value, which was indicative of the highest antioxidant activity, although the extracts had generally low activity in the PRAP assay. The leaf methanol extract of Cupressus sempervirens var. horizantalis was the most active one. Concerning the results obtained from the metal-chelation assay, the cone and leaf methanol extracts of both varieties did not possess metal-chelation capacity. However, the leaf ethyl acetate extracts of Cupressus sempervirens var. horizantalis $(75.86 \pm 0.33 \%)$ and Cupressus sempervirens var. pyramidalis $(77.07 \pm 3.22 \%)$ showed the highest activity in this assay [162].

The antioxidant activity of Cupressus sempervirens essential oil was evaluated by measuring the radicals-scavenging effect on 2, 2-diphenyl-1-picrylhydrazyl (DPPH) and by using the 2, 2'-azinobis(3ethylbenzothiazoline-6-sulfonate) (ABTS) assay. Essential oil showed high antioxidant activity $(7.7 \mu \mathrm{g} / \mathrm{ml}$ and $2.14 \mathrm{mM}$ Trolox for DPPH and ABTS assays, respectively) when compared to BHT [163].

The antioxidant and anti-glycation properties of branchlet and fruit oils of Cupressus sempervirens var. horizontalis were studied after extraction of essential oils. Essential oils were extracted from the branchlets and fruits of Cupressus sempervirens var. horizontalis using the steam distillation method. A gas chromatography-mass spectrometry method was employed for the compositional analysis of essential oils. In order to evaluate antioxidant activities of oils at different concentrations (180, 220 and $260 \mu \mathrm{g} / \mathrm{ml})$, linoleic acid peroxidation test and peroxyl radical mediated hemolysis of red blood cells (RBC) assay were used. Linoleic acid peroxidation was monitored for $4 \mathrm{~h}$ and determined during each hour of incubation. Antiglycation effects of oils at 200, 400 and $600 \mu \mathrm{g} / \mathrm{ml}$ were assessed using hemoglobin and insulin glycation assays. Hemoglobin glycation was inhibited by both branchlet $(44.8,62.6$ and $54.0 \%)$ and fruit $(41.0,62.8$ and $48.5 \%)$ at 200,400 and $600 \mu \mathrm{g} / \mathrm{ml}$ of oil respectively. Insulin glycation inhibitory rates were $(66.1,69.2$ and $73.8 \%)$ for branchlet oil, and (80.0, 76.9 and $81.5 \%$ ) for fruit oil at 200, 400 and $600 \mu \mathrm{g} / \mathrm{ml}$, respectively. RBC hemolysis was also inhibited by both branchlet oil (49.9, 38.5 and 15.0\%) and fruit oil (45.9, 38.6 and 25.0\%) at 180, 220 and 260 $\mu \mathrm{g} / \mathrm{ml}$, respectively. Finally, the oils mitigated linoleic acid peroxidation which was peaked after $4 \mathrm{~h}$ for both branchlet $(39.5,35.6$ and 53.4\%) and fruit $(47.5,58.6$ and $59.8 \%)$ at 180,220 and $260 \mu \mathrm{g} / \mathrm{ml}$ of oil respectively [164].

The antioxidant activities of hydroethanolic extract of leaves of Cupressus sempervirens was studied in vitro in comparison with ascorbic acid, and their correlation with in vivo hepatoprotective activity in rat model of paracetamol-induced hepatotoxicity. In vitro study revealed that the tested extracts contained abundant amount of phenolic and flavonoids compounds attributed to their effective antioxidant potential in different 
models. In in vivo study, the pre-treatments with extract $(250 \mathrm{mg} / \mathrm{kg} / \mathrm{day}$, po) or silymarin $(100 \mathrm{mg} / \mathrm{kg} / \mathrm{day}, \mathrm{po})$ for 4 weeks have good safety profile in normal rats and exhibited a marked hepatoprotection against single toxic dose of paracetamol ( $4 \mathrm{~g} / \mathrm{kg}$ bw, po), significant preserving the normal liver function parameters, maintenance the hepatic redox status as evident from significant increase in antioxidant enzyme activities and reduced glutathione with inhibition of lipid peroxidation and protein oxidation, decreasing nitric oxide and tumor necrosis factor alpha, membrane stabilizing effects as confirmed from significant increase in the hepatic $\mathrm{Na}^{+}-$ $\mathrm{K}^{+}$-ATPase activity and decrease in lysosomal enzyme activities which were changed in the untreated paracetamol-intoxicated rats [165].

\section{Cydonia oblonga}

In comparison of antioxidant potential of quince leaf and green tea (Camellia sinensis). Quince leaf exhibited a significantly higher reducing power than green tea $(227.8 \pm 34.9$ and $112.5 \pm 1.5 \mathrm{~g} / \mathrm{kg} \mathrm{dry} \mathrm{leaf}$, respectively), but showed similar 2,2'-diphenyl-1-picrylhydrazyl (DPPH) radical-scavenging activities. Quince leaf methanolic extract significantly protected the erythrocyte membrane from hemolysis under the oxidative action of 2,2'-azobis(2-amidinopropane) dihydrochloride [166-167].

The radical scavenging potential of the extracts was determined and compared with that of synthetic antioxidants. The stronger properties corresponded to those obtained from peel material with a 70-80\% inhibitory effect on DPPH radicals [167-168].

The antioxidant functions of quince phenolic extracts were superior to that of chlorogenic acid and ascorbic acid, evaluated in both the linoleic acid peroxidation system and the DPPH radical scavenging system [169]. The antioxidant activity of quince fruit (pulp, peel, and seed) and jam, methanolic extracts were fractionated into a phenolic fraction and an organic acid fraction and were analyzed by high-performance liquid chromatography/diode array detection and HPLC/UV. Antiradical activities of the extracts and fractions were evaluated by a microassay using 1,1'-diphenyl-2-picrylhydrazyl. The phenolic fraction exhibited a stronger antioxidant activity than the whole methanolic extract. Organic acid extracts were the weakest in terms of antiradical activity, which indicated that the phenolic fraction gave a higher contribution for the antioxidant potential of quince fruit and jam. The evaluation of the antioxidant activity of methanolic extracts showed that peel extract exerted the highest antioxidant capacity. The $\mathrm{IC}_{50}$ values of quince pulp, peel, and jam extracts were correlated with the caffeoylquinic acids content. Among the phenolic fractions, the seed extract was the one that exhibited the strongest antioxidant activity [170].

Cydonia oblonga fruit were separated into pulps, peels and seeds and methanolic extracts of these parts were prepared. Antioxidant properties were studied for their ability to quench the stable free radical 2,2'diphenyl-1-picrylhydrazyl (DPPH) and to inhibit the 2,2'-azobis(2-amidinopropane) dihydrochloride (AAPH)induced oxidative hemolysis of human erythrocytes. Pulp and peel extracts showed similar DPPH free radical scavenging activities $\left(\mathrm{EC}_{50}\right.$ of 0.6 and $0.8 \mathrm{mg} / \mathrm{ml}$, respectively), while seed extract presented much lower antioxidant potential $\left(\mathrm{EC}_{50}\right.$ of $\left.12.2 \mathrm{mg} / \mathrm{ml}\right)$. Under the oxidative action of AAPH, pulp and peel extracts showed significant protection of the erythrocyte membrane from hemolysis, in a time- and concentration-dependent manner [171].

The antioxidant potential of Cydonia oblonga leaf, compared with green tea, was studied by FolinCiocalteu reducing capacity assay and by the ability to quench the stable free radical 2,2'-diphenyl-1picrylhydrazyl (DPPH) and to inhibit the 2,2'-azobis(2-amidinopropane) dihydrochloride (AAPH)-induced oxidative hemolysis of human erythrocytes. Quince leaf exhibited a significantly higher reducing power than green tea (mean value of $227.8 \pm 34.9$ and $112.5 \pm 1.5 \mathrm{~g} / \mathrm{kg}$ dry leaf, respectively). Quince leaf extracts showed similar DPPH radical-scavenging activities $\left(\mathrm{EC}_{50}\right.$ mean value of $\left.21.6 \pm 3.5 \mathrm{microg} / \mathrm{ml}\right)$ but significantly lower than that presented by green tea extract $\left(\mathrm{EC}_{50}\right.$ mean value of $\left.12.7 \pm 0.1 \mathrm{microg} / \mathrm{ml}\right)$. Under the oxidative action of AAPH, quince leaf methanolic extract significantly protected the erythrocyte membrane from hemolysis in a similar manner to that found for green tea $\left(\mathrm{IC}_{50}\right.$ mean value of $30.7 \pm 6.7$ and $24.3 \pm 9.6 \mathrm{microg} / \mathrm{ml}$, respectively, $\mathrm{P}>0.05)$ [166-167].

The antioxidant effects of lipophilic quince wax extract (QWE) and an aqueous fermented one (QAFE) were studied including their radical scavenging and reductive power as well as their antilipoperoxidative properties. The Quince Aqueous fermented extract (QAFE) effectively scavenged the radical target species exhibiting $\mathrm{ID}_{50}$ values equal to $68.8 \mu \mathrm{g} / \mathrm{ml}$ towards $\mathrm{DPPH} \cdot$ and $73.7 \mu \mathrm{g} / \mathrm{ml}$ towards the anion superoxide radical. Quince wax extract (QWE) was more effective at preventing the formation of thiobarbituric reactive species than QAFE, exhibiting an ID $_{50}$ value equal to $48.9 \mu \mathrm{g} / \mathrm{ml}[172]$.

\section{Cymbopogon schoenanthus}

The antioxidant activity of the essential oils from fresh leaves, dried leaves and roots of Cymbopogon schoenanthus was assayed using $\beta$-carotene-linoleic acid bleaching method. The best results $\left(\mathrm{IC}_{50}=0.47 \pm 0.04 \mathrm{mg} / \mathrm{ml}\right)$ were obtained with the fresh leaves of plants collect in the desert region in southern Tunisia [173]. 
Aqueous extract, proanthocyanidin rich extract, and organic extracts of Cymbopogon schoenanthus shoots from three different locations in south Tunisia were screened for their antioxidant activity. Antioxidant activity measured by DPPH assay showed that the proanthocyanidin extract exhibited higher antioxidant activity than the aqueous extract. Extract concentration providing 50\% inhibition $\left(\mathrm{IC}_{50}\right)$ ranged from $16.4 \pm 6.8 \mu \mathrm{g} / \mathrm{ml}$ to $26.4 \pm 6.8 \mu \mathrm{g} / \mathrm{ml}$. The antioxidant activity was also determined using the $\beta$-carotene/linoleic acid bleaching test. The best results $\left(\mathrm{IC}_{50}=0.11 \pm 0.10 \mathrm{mg} / \mathrm{ml}\right)$ were obtained with the proanthocyanidin extract of the plants collected from the desert region (Dhibat) in Tunisia [174].Antioxidant activity of the essential oils of Cymbopogon schoenanthus was measured by DPPH assay. The results of antioxidant effect ranged from $36.0 \%$ to $73.8 \%$ ( $2 \mu 1$ of essential oil per $\mathrm{ml}$ of test solution) [173].

\section{Cynodon dactylon}

The effect of ethylacetate fractions of Cynodon dactylon on the level of enzymic and non enzymic antioxidants was studied in Ehrlich's lymphoma ascite (ELA) transplanted mice. The levels of enzymic antioxidants like super oxide dismutase, glutathione peroxidase and catalase and non enzymic antioxidants like reduced glutathione, vitamin A and vitamin E, were decreased in ELA induced mice due to the liberation of free radicals from the liver. Administration of ethylacetate extract ( $80 \mu \mathrm{g}$ in $100 \mu \mathrm{l}$ of DMSO, ip ) increased levels of enzymic and non enzymic antioxidants in ELA transplanted mice [175].

Cynodon dactylon was sequentially extracted with hexane, ethyl acetate, and methanol, then the extracts were concentrated and tested for antioxidant activity using 1,1-diphenyl-2-picrylhydrazyl, nitric oxide and 3-(4,5-dimethylthiazol-2-yl)-2,5-diphenyl tetrazolium bromide assays on four cancer cell lines and a normal cell line. The anticancer potential of cytotoxic extracts was determined by the Annexin-fluorescein isothiocyanate-conjugated assay in human colon adenocarcinoma cell lines (COLO 320 DM). Cynodon dactylon extracts showed significant antioxidant and antiproliferative activities [176].

The antioxidant activity of the hydroalcoholic extract of aerial parts of Cynodon dactylon was studied in vitro by different methods (DPPH radical scavenging activity, superoxide anion radical scavenging assay, nitric oxide scavenging assay, ferrous chelating ability, hydroxyl radical scavenging assay, hydrogen peroxide scavenging activity and ABTS assay). In all the methods, the extract showed ability to scavenge free radicals in a concentration dependant manner. Superoxide anion radical scavenging assay showed a maximum inhibition of 93.33\%. Total antioxidant capacity equivalent of ascorbic acid was $172.39 \mathrm{mg} / \mathrm{g}$ of extract [177].

Selected isolates from ethyl acetate extract of Cynodon dactylon and piper betle and the combination of both were found to have antioxidant activity. The selected isolates showed better activities in combination rather than individual form [178].

\section{Cyperus rotuntdus}

Antioxidant activity of Cyperus rotundus rhizomes extract (CRRE) was evaluated in a series of in vitro assay. CRRE exhibited scavenging effect in concentration dependent manner on superoxide anion radicals, hydroxyl radicals, nitric oxide radical, hydrogen peroxide, in addition to property of metal chelating and reducing power. The lipid peroxidation effect of the extract was also studied by thiobarbituric acid-reactive substances (TBARS) using young and aged rat brain mitochondria. The extract prevented mitochondrial lipid peroxidation induced by $\mathrm{FeSO}_{4}$ ascorbate in concentration dependent manner [179].

Cyperus rotundus extracted by different extraction solvents was evaluated for antioxidant activity using different in vitro antioxidant assays. Total flavonoids and polyphenols contents in methanol extracts of Cyperus rotundus were higher compared to ethanol extracts. Percent inhibition of linoleic acid system of methanol extracts of Cyperus rotundus (32.50-48.17\%), DPPH free radical scavenging capacity (51.50-61.73\%) and reducing power (0.754-1.112) were higher as compared to ethanol extracts at concentration of $2.5-10.0 \mathrm{mg} / \mathrm{ml}$ [180].

\section{III- CONCLUSION}

The paper reviewed the medicinal plants and herbs which showed antioxidant and free radical scavenging activities to be utilized in several medical applications because of their effectiveness and safety.

\section{REFERENCES}

[1] Orhan IE . Biotechnological production of plant secondary metabolites. Bentham ebook, 2012: 107.

[2] Al-Snafi AE. Chemical constituents and pharmacological activities of Milfoil (Achillea santolina) - A Review. Int J Pharm Tech Res 2013, 5(3): 1373-1377.

[3] Al-Snafi AE. The chemical constituents and pharmacological effects of Adiantum capillus-veneris- A review. Asian Journal of Pharmaceutical Science and Technology 2015; 5(2): 106-111.

[4] Al-Snafi AE. The pharmacological and therapeutic importance of Agrimonia eupatoria- A review. Asian Journal of Pharmaceutical Science and Technology 2015; 5(2): 112-117.

[5] Al-Snafi AE. The pharmacological importance of Ailanthus altissima- Areview. International Journal of Pharmacy Review and Research 2015; 5(2): 121-129. 
[6] Al-Snafi AE. Alhagi maurorum as a potential medicinal herb: An Overview. International Journal of Pharmacy Review and Research 2015; 5(2):130-136.

[7] Al-Snafi AE. Pharmacological effects of Allium species grown in Iraq. An overview. International Journal of Pharmaceutical and health care Research 2013;1(4):132-147.

[8] Al-Snafi AE. The pharmacological activities of Alpinia galangal - A review. International Journal for Pharmaceutical Research Scholars 2014; 3(1-1): 607-614.

[9] Al-Snafi AE. The Pharmaceutical importance of Althaea officinalis and Althaea rosea: A Review. Int J Pharm Tech Res 2013; 5(3):1387-1385.

[10] Al-Snafi AE. The chemical constituents and pharmacological effects of Ammannia baccifera - A review. International Journal of Pharmacy 2015; 5(1): 28-32.

[11] Al-Snafi AE. Chemical constituents and pharmacological activities of Ammi majus and Ammi visnaga. A review. International Journal of Pharmacy and Industrial Research 2013; 3(3):257-265.

[12] Al-Snafi AE. The pharmacology of Anchusa italica and Anchusa strigosa - A review. International Journal of Pharmacy and Pharmaceutical Sciences 2014; 6(4): 7-10.

[13] Al-Snafi AE. The pharmacological importance of Anethum graveolens - A review. International Journal of Pharmacy and Pharmaceutical Sciences 2014; 6(4): 11-13.

[14] Al-Snafi AE. Medical importance of Antemis nobilis ( Chamaemelum nobilis)- A eview. Asian Journal of Pharmaceutical Science \& Technology 2016; 6(2): 89-95.

[15] Al-Snafi AE. The pharmacological Importance of Antirrhinum majus - A review. Asian J of Pharm Sci \& Tech 2015; 5(4): 313-320.

[16] Al-Snafi AE. Chemical constituents and pharmacological activities of Arachis hypogaea. - A review. International Journal for Pharmaceutical Research Scholars 2014; 3(1-1): 615-623.

[17] Al-Snafi AE. The Pharmacological importance and chemical constituents of Arctium Lappa. A review. International Journal for Pharmaceutical Research Scholars 2014; 3(1-1): 663-670.

[18] Al-Snafi AE. The pharmacological importance of Artemisia campestris- A review. Asian Journal of Pharmaceutical Research 2015;5(2): 88-92.

[19] Al-Snafi AE. The pharmacological importance of Asparagus officinalis - A review. Journal of Pharmaceutical Biology 2015; 5(2): 93-98.

[20] Al-Snafi AE. Chemical constituents and pharmacological effects of Astragalus hamosus and Astragalus tribuloides grown in Iraq. Asian J of Pharm Sci \& Tech 2015; 5(4): 321-328.

[21] Al-Snafi AE. The nutritional and therapeutic importance of Avena sativa - An Overview. International Journal of Phytotherapy 2015; 5(1): 48-56.

[22] Al-Snafi AE. The pharmacology of Bacopa monniera. A review. International Journal of Pharma Sciences and Research 2013; 4(12): 154-159.

[23] Al-Snafi AE. The Pharmacological Importance of Ballota nigra -A review. Ind J of Pharm Sci \& Res 2015; 5(4): 249-256.

[24] Al-Snafi AE. The Pharmacological importance of Bauhinia variegata. A Review. International Journal of Pharma Sciences and Research 2013; 4(12): 160-164.

[25] Al-Snafi AE. The Pharmacological importance of Bellis perennis - A review. International Journal of Phytotherapy 2015; 5(2): 63-69.

[26] Al-Snafi AE. Chemical constituents and pharmacological importance of Bidens tripartitus - A review. Ind J of Pharm Sci \& Res 2015; 5(4): 257-263.

[27] Al-Snafi AE. The pharmacological importance of Brassica nigra and Brassica rapa grown in Iraq. J of Pharm Biology 2015; 5(4): 240-253.

[28] Al-Snafi AE. The Chemical constituents and pharmacological effects of Bryophyllum calycinum. A review. Journal of Pharma Sciences and Research 2013; 4(12): 171-176.

[29] Al-Snafi AE. Pharmacology and medicinal properties of Caesalpinia crista - An overview. International Journal of Pharmacy 2015; 5(2): 71-83.

[30] Al-Snafi AE. Encyclopedia of the constituents and pharmacological effects of Iraqi medicinal plants. Thi qar University, 2013

[31] Al-Snafi AE. The chemical constituents and pharmacological effects of Calendula officinalis - A review. Indian Journal of Pharmaceutical Science \& Research 2015; 5(3): 172-185.

[32] Al-Snafi AE. The constituents and pharmacological properties of Calotropis procera - An Overview. International Journal of Pharmacy Review \& Research 2015; 5(3): 259-275.

[33] Al-Snafi AE. Bioactive components and pharmacological effects of Canna indica- An Overview. International Journal of Pharmacology and toxicology 2015; 5(2):71-75.

[34] Al-Snafi AE. The chemical constituents and pharmacological effects of Capparis spinosa - An overview. Indian Journal of Pharmaceutical Science and Research 2015; 5(2): 93-100. 
[35] Al-Snafi AE. The pharmacological importance of Capsicum species (Capsicum annuum and Capsicum frutescens) grown in Iraq. Journal of Pharmaceutical Biology 2015; 5(3): 124-142.

[36] Al-Snafi AE. The chemical constituents and pharmacological importance of Carthamus tinctorius - An overview. Journal of Pharmaceutical Biology 2015; 5(3): 143-166.

[37] Al-Snafi AE. The chemical constituents and pharmacological effects of Carum carvi - A review. Indian Journal of Pharmaceutical Science and Research 2015; 5(2): 72-82.

[38] Al-Snafi AE. The therapeutic importance of Cassia occidentalis - An overview. Indian Journal of Pharmaceutical Science \& Research 2015; 5 (3): 158-171.

[39] Al-Snafi AE. The pharmacological importance of Casuarina equisetifolia - An Overview. International Journal of Pharmacological Screening Methods 2015; 5(1): 4-9.

[40] Al-Snafi AE. The pharmacological importance of Centaurea cyanus- A review. Int J of Pharm Rev \& Res 2015; 5(4): 379-384.

[41] Al-Snafi AE. The chemical constituents and pharmacological effects of Chenopodium album - An overview. International J of Pharmacological Screening Methods 2015; 5(1): 10-17.

[42] Al-Snafi AE. The chemical constituents and pharmacological importance of Chrozophora tinctoria. Int J of Pharm Rev \& Res 2015; 5(4): 391-396.

[43] Al-Snafi AE. Therapeutic properties of medicinal plants: a review of plants with antioxidant activity (part 1). International Journal of Pharmacology and Toxicology 2015; 6(3): 159-182.

[44] Sahana C, Zehra A, Madhusudana K, Kumar DA and Agawane SB. Mitigation of starch-induced postprandial glycemic spikes in rats by antioxidants-rich extract of Cicer arietinum Linn. seeds and sprouts. J Pharm Bioallied Sci 2013; 5(4):270-276.

[45] Al-Snafi AE. The medical Importance of Cicer arietinum - A review IOSR Journal of Pharmacy 2016; 6(3): 29-40.

[46] Tom B and Thiruselyi M. Comparison of free radical scavenging activity of two main varieties of Cicer arietinum sprouts. Int Res J Pharm 2013; 4(6): 168-170.

[47] Hooda MS and Pal R. Antioxidant potential and free radical scavenging activity by Cicer arietinum Linn. Int J Pharm Bio Sci 2012; 3(4): 274-281.

[48] Balaji P, Arun BP, Kumar S, Sundaram M and Brindha P. Isolation and identification of adaptogenic protein from Cicer arietinum Linn. International Journal of Pharmacy and Pharmaceutical Sciences 2012; 4(12):79-84.

[49] Vadnere GP, Patil AV, Wagh SS and Jain SK. In vitro free radical scavenging and antioxidant activity of Cicer arietinum L. (Fabaceae). Int J PharmTech Res 2012; 4(1): 343-350.

[50] Ramachandra MS, Rao AS and Rani SS. Hepatoprotective and antioxidant activities of areal parts ( except fruits) of Cicer arietinum against carbon tetrachloride induced hepatotoxicity in rats. Int J Pharm 2014; 4(1): 431-436.

[51] Santhoshi K, Teja. Divya BS and Ravi KV. Potential hepatoprotective effect of ethanolic seeds extract of Cicer arietinum against paracetamol induced hepatotoxicity. Journal of Pharmacy Research 2013; 6(9):924.

[52] Mehmood N, Zubair M, Rizwan K, Rasool N Shahid M and Ahmad VU. Antioxidant, antimicrobial and phytochemical analysis of Cichorium intybus seeds extract and various organic fractions. Iranian Journal of Pharmaceutical Research 2012; 11 (4): 1145-1151.

[53] Ahmed N. Alloxan diabetes-induced oxidative stress and impairment of oxidative defense system in rat brain: neuroprotective effects of cichorium intybus. Int J Diabetes \& Metabolism 2009;17:105-109.

[54] Al-Snafi AE. Medical importance of Cichorium intybus - A review IOSR Journal of Pharmacy 2016; 6(3): 41-56.

[55] Gazzani G, Daglia M, Papetti A and Gregotti C. In vitro and ex vivo anti- and prooxidant components of Cichorium intybus. J Pharm Biomed Anal 2000; 23(1): 127-133.

[56] Shad MA, Nawaz H, Rehman T and Ikram N. Determination of some biochemicals, phytochemicals and antioxidant properties of different parts of Cichorium intybus L.: A comparative study. The Journal of Animal \& Plant Sciences 2013; 23(4): 1060-1066.

[57] Lee YH, Kim DH, Kim YS and Kim TJ. Prevention of oxidative stress-induced apoptosis of C2C12 myoblasts by a Cichorium intybus root extract. Biosci Biotechnol Biochem 2013;77(2):375-377.

[58] Liu H, Wang Q, Liu Y, Chen G and Cui J. Antimicrobial and antioxidant activities of Cichorium intybus root extract using orthogonal matrix design. J Food Sci 2013; 78(2): M258-263.

[59] Delazar A, Gibbons S, Kosari A, Nazemiyeh H, Modarresi MM, Nahar L and Sarker SD. Flavoneglycosides and cucurbitacin glycosides from Citrullus colocynthis. DARU 2006; 14(3): 109-114.

[60] Al-Snafi AE. Chemical constituents and pharmacological effects of Citrullus colocynthis - A review. IOSR Journal of Pharmacy 2016; 6(3): 57-67. 
[61] Kumar S, Kumar D, Manjush A, Saroha K, Singh N and Vashishta B. Antioxidant and free radical scavenging potential of Citrullus colocynthis (L.) Schrad. methanolic fruit extract. Acta Pharm 2008; 58: 215-220.

[62] Benariba N, Djaziri R, Bellakhdar W, Belkacem N, Kadiata M, malaise W, and Sener A. Phytochemical screening and free radical scavenging activity of Citrullus colocynthis seeds extracts. Asian Pacific Journal of Tropical Biomedicine 2013; 3(1): 35-40.

[63] Gill NS, Kaur S, Arora R and Bail M. Screening of antioxidant and antiulcer potential of Citrullus colocynthis methanolic seed extract. Research Journal of Phytochemistry 2011;5(2): 98-106.

[64] Jayaraman R and Christina AJM. Evaluation of Citrullus colocynthis fruits on in vitro antioxidant activity and in vivo DEN/PB induced hepatotoxicity. International Journal of Applied Research in Natural Products 2013; 6 (1): 1-9.

[65] Reddy LJ, Jalli1RD, Jose B and Gopu S. Evaluation of antibacterial \& antioxidant activities of the leaf essential oil \& leaf extracts of Citrus aurantifolia. Asian Journal of Biochemical and Pharmaceutical Research 2012; 2(2): 346-354.

[66] Boshtam M, Moshtaghian J, Naderi G, Asgary S and Nayeri H. Antioxidant effects of Citrus aurantifolia (Christm) juice and peel extract on LDL oxidation. J Res Med Sci 2011; 16(7): 951-955.

[67] Menichini F. Evaluation of Citrus aurantifolia peel and leaves extracts for their chemical composition, antioxidant and anti-cholinesterase activities. J Sci Food Agric 2002; 92: 2960-2967.

[68] Kumari S, Sarmah N and Handique AK. Antioxidant activities of the unripen and ripen Citrus aurantifolia of Assam. International Journal of Innovative Research in Science, Engineering and Technology 2013; 2(9): 4811-4816.

[69] Shajie D, Wadhwa N, Murthy NBK and Rashmi M. antioxidant efficacy of Citrus limonum pulp and peel- An in vitro study. Drug Invention Today 2013; 5(4): 296-301.

[70] Campêlo LML, de Almeida AAC, de Freitas RLM, Cerqueira GS, Saldanha GB, Feitosa $\mathrm{CM}$, and de Freitas RM. Antioxidant and antinociceptive effects of Citrus limon essential oil in mice. J Biomed Biotechnol 2011; doi: 10.1155/2011/678673

[71] Campêlo LML, Gonçalves FCM, Feitosa CM and Freitas RM. Antioxidant activity of Citrus limon essential oil in mouse hippocampus. Pharm Biol 2011;49:709-715.

[72] Bertuzzi G, Tirillini B, Angelini P and Venanzoni R. Antioxidative action of Citrus limonum essential oil on skin. European Journal of Medicinal Plants 2013; 3(1): 1-9.

[73] Hetta MH, El-Alfy TS, Yassin NZ, Abdel-Rahman RF and Kadry EM. Phytochemical and antihyperglycemic studies on Citrus medica 1. leaves (Etrog) growing in Egypt. International Journal of Pharmacognosy and Phytochemical Research 2013-14; 5(4); 271-277.

[74] Sood S, Bansal S, Muthuraman A, Gill NS and Bali M. Therapeutic potential of Citrus medica L peel extract in carrageenan induced inflammatory pain in rat. Res J Med Plant 2009; 3: 123-133.

[75] Conforti F, Giancarlo AS, Tundis R, Loizzo MR and Menichini F. In vitro activities of Citrus medica L cv. Diamante (Diamante citron) relevant to the treatment of diabetes and Alzheimer's disease. Phytotherapy Research. 2007; 21(5):427-33.

[76] Kabra AO, Bairagi GB and Wanare RS. K Antidiabetic activity of ethanol extract of Citrus medica L. peels in streptozotocin induced diabetic rats. Journal of Pharmacy Research 2012; 5(3):1287-1289.

[77] Javed S, Ahmad R, Shahzad K, Nawaz S, Saeed S and Saleem Y. Chemical constituents, antimicrobial and antioxidant activity of essential oil of Citrus limetta var. Mitha (sweet lime) peel in Pakistan. Afr J Microbiol Res 2013; 7(24) 3071-3077.

[78] KunduSen S, Saha P, Bhattacharya S, Bala A, Mazumder UK, Gupta M and Haldar PK. Evaluation of in vitro antioxidant of Citrus limmetta and Citrus maxima on reactive oxygen and nitrogen species. Pharmacologyonline 2010; 3: 850-857.

[79] Mohanty S, Maurya AK, Jyotshna, Saxena A, Shanker K, Pal A and Bawankule DU. Flavonoids rich fraction of Citrus limetta fruit peels reduces proinflammatory cytokine production and attenuates malaria pathogenesis. Curr Pharm Biotechnol 2015;16(6):544-552.

[80] Vinson JA, Su X, Zubik L and Bose P. Phenol antioxidant quantity and quality in foods: fruits. J Agric Food Chem 2001; 49:5315-5321.

[81] Gorinstein S, Martin-Belloso O, Park Y, Haruenkit R, Lojek A, Ciz M, Hamidinia A and Jafari M. Comparison of some biochemical characteristics of different citrus fruits. Food Chem 2001; 74:309-315.

[82] Asjad HMM, Akhtar MS, Bashir S, Din B, Gulzar F, Khalid R and Asad M. Phenol, flavonoid contents and antioxidant activity of six common citrus plants in Pakistan. Journal of Pharmaceutical and Cosmetic Sciences 2013; 1(1):1-5.

[83] Rekha SS and Bhaskar M. In vtro screening and identification of antioxidant activities of orange (Citrus sinensis) peel extract in different solvents. Int J Pharm Bio Sci 2013; 4(4): (P) 405 - 412 
[84] Al-Ashaal HA and El-Sheltawy ST. Antioxidant capacity of hesperidin from citrus peel using electron spin resonance and cytotoxic activity against human carcinoma cell lines. Pharm Biol 2011; 49(3):276282.

[85] Pereira-Caro G, Borges G, van der Hooft J, Clifford MN, Del Rio D, Lean ME, Roberts SA, Kellerhals MB and Crozier A. Orange juice (poly)phenols are highly bioavailable in humans. Am J Clin Nutr 2014;100(5):1378-1384.

[86] Prasad MP, Sushant S and Chikkaswamy BK. Phytochemical analysis , antioxidant potential, antibacterial activity and molecular characterization of Clerodendrum species. International Journal of Molecular Biology 2012;3(3): 71-76.

[87] Al-Snafi AE. Chemical constituents and pharmacological effects of Clerodendrum inerme- A review. SMU Medical Journal 2016; 3(1): 129-153.

[88] Gurudeeban S, Satyavani K, Ramanathan T, Umamaheswari G, Shanmugapriya R. Antioxidant and Radical Scavenging Effect of Clerodendrum inerme (L.) Global Journ of Pharmacology 2010; 4(2):9194.

[89] Ibrahim SRM, Alshali KZ, Fouad MA, Elkhayat ES, Al Haidari R and Mohamed GA. Chemical constituents and biological investigations of the aerial parts of Egyptian Clerodendrum inerme. Bulletin of Faculty of Pharmacy, Cairo University 2014; 52(2): 165-170.

[90] Mukhopadhyay R, Bhattacharya S and Biswas M. In vitro free radical scavenging activity of Clitoria ternatea leaf extracts. Journal of Advanced Pharmacy Education \& Research 2012; 2(4):206-209.

[91] Al-Snafi AE. Pharmacological importance of Clitoria ternatea - A review IOSR Journal of Pharmacy 2016; 6(3): 68-83.

[92] Patil AP and Patil VR. Comparative evaluation of in vitro antioxidant activity of root of blue and white flowered varieties of Clitoria ternatea Linn. International Journal of Pharmacology 2011; 7(4):485-491.

[93] Patil AP and Patil VR. Evaluation of in vitro antioxidant activity of seeds of blue and white flowered varieties of Clitoria ternatea Linn. International Journal of Pharmacy and Pharmaceutical Sciences 2011; 3(4): 330-336.

[94] Sivaprabha J, Supriya J, Sumathi S, Padma PR, Nirmaladevi R and Radha P. A study on the levels of nonenzymic antioxidants in the leaves and flowers of Clitoria ternatea. Anc Sci Life 2008; 27(4): 2832.

[95] Phrueksanan W, Yibchok-anun S and Adisakwattana S. Protection of Clitoria ternatea flower petal extract against free radical-induced hemolysis and oxidative damage in canine erythrocytes. Res Vet Sci 2014;97(2):357-363.

[96] Balakrishnan B, Ayyavoo J, Sadayan P and Abimannan A. Evaluation of antioxidant activity of Clitoria ternatea and Alternanthera sessilis plant extracts using model system for yeast cells. African Journal of Basic \& Applied Sciences 2013; 5 (3): 134-138.

[97] Kamkaen N and Wilkinson JM. The antioxidant activity of Clitoria ternatea flower petal extracts and eye gel. Phytother Res 2009; 23(11):1624-1625.

[98] Jayakar B and Suresh B. Hepatoprotective potential of Clitoria ternatea leaf extract against paracetamol induced damage in mice. Molecules 2011; 16: 10134-10145.

[99] Sevim D, Senol FS, Budakoglu E, Orhan IE, Bilge S and Kaya E. Studies on anticholinesterase and antioxidant effects of samples from Colchicum L. genus of Turkish origin. Fabad J Pharm. Sci 2010; 35: 195-201.

[100] Mammadov R, Düsen O, Uysal D and Köse E. Antioxidant and antimicrobial activities of extracts from tubers and leaves of Colchicum balansae Planchon. Journal of Medicinal Plants Research 2009; 3(10): 767-770.

[101] Azman NAM, Gallego MG, Juliá L, Fajari L and Almajano MP. The effect of Convolvulus arvensis dried extract as a potential antioxidant in food models. Antioxidants 2015; 4: 170-184.

[102] Thakra J, Borar S and Kalia AN. Antioxidant potential fractionation from methanol extract of aerial parts of Convolvulus arvensis Linn. (Convolvulaceae). International Journal of Pharmaceutical Sciences and Drug Research 2010; 2(3): 219-223.

[103] Elzaawely AA and Tawata S. Antioxidant activity of phenolic rich fraction obtained from Convolvulus arvensis L. leaves grown in Egypt. Asian Journal of Crop Science 2012; 4(1): 32-40.

[104] Patel RP and Patel MP. Evaluation of antioxidant activity of Corchorus aestuans Linn leaves extracts. International Research Journal of Pharmacy 2012; 3(7):233-238.

[105] Patel R and Patel M. Antioxidant activity of isolated flavonoids from the leaves of Corchorus aestuans Linn. IJPSR 2013; 4(1): 334-340.

[106] Zakaria ZA. Free radical scavenging activity of some plants available in Malaysia. Iranian Journal of Pharmacology and Therapeutics 2007; 6(1):87-91. 
[107] Al-Snafi AE. The contents and pharmacological importance of Corchorus capsularis- A review. IOSR Journal of Pharmacy 2016; 6(6): 58-63.

[108] Rume JM. Phytochemical, antimicrobial and biological investigations of methanolic extract of leaves of Corchorus capsularis. Thesis for bachelor degree of pharmacy, East West University 2010.

[109] Souri E, Amin G, Farsam H and Barazandeh TM. Screening of antioxidant activity and phenolic content of 24 medicinal plant extracts. DARU 2008; 16(2): 83-87.

[110] Al-Snafi AE. The Pharmacological and therapeutic importance of Cordia myxa- A review. IOSR Journal of Pharmacy 2016; 6(6): 47-57.

[111] Afzal M, Obuekwe C, Khan AR and Barakat H. Antioxidant activity of Cordia myxa L. and its hepatoprotective potential. EJEAF Che 2007; 8(6): 2236-2242.

[112] Afzal M, Obuekwe C, Khan AR and Barakat H. Influence of Cordia myxa on chemically induced oxidative stress. Nutrition \& Food Science 2009; 39(1): 6-15.

[113] Haq MA, Azam M and Hasnain A. Gum cordia as carrier of antioxidants: effects on lipid oxidation of peanuts. J Food Sci Technol 2015; 52(4):2366-2372.

[114] Melo EA, Filho JM and Guerra NB. Characterization of antioxidant compounds in aqueous coriander extract (Coriandrum sativum L.). Food Sci Technol 2005; 38(1): 15-19.

[115] Wong PY and Kitts DD. Studies on the dual antioxidant and antibacterial properties of parsley (Petroselinum crispum) and cilantro (Coriandrum sativum) extracts. Food Chem 2006;97:505-515.

[116] Hashim MS, Lincy S, Remya V, Teena M and Anila L. Effect of polyphenolic compounds from Coriandrum sativum on $\mathrm{H}_{2} \mathrm{O}_{2}$-induced oxidative stress in human lymphocytes. Food Chem. 2005;92:653660 .

[117] Wangensteen H, Samuelsen AB and Malterud KE. Antioxidant activity in extracts from coriander. Food Chem 2004; 88: 293-297.

[118] Panjwani D, Mishra B and Banji D. Time dependent antioxidant activity of fresh juice of leaves of Coriandrum sativum. International Journal of Pharmaceutical Sciences and Drug Research 2010; 2(1): 63-66.

[119] Reddy LH, Jalli RD, Jose B and Gopu S. Evaluation of antibacterial and DPPH radical scavenging activities of the leaf extracts and essential oil of Coriandrum sativum Linn. World Journal of Pharmaceutical research 2012; 1(3): 705-716.

[120] Chauhan KPK, Jaryal M, Kumari K and Singh M. Phytochemical and in vitro antioxidant potential of aqueous leaf extracts of Brassica juncea and Coriandrum sativum. IJPSR 2012; 3(8): 2862-2865.

[121] Ramadan MM and Abd Algader NNE. Chemopreventive effect of Coriandrum sativum fruits on hepatic toxicity in male rats. World Journal of Medical Sciences 2013; 8 (4): 322-333.

[122] Anilakumar KR, Nagaraj NS, Santhanam K. Effect of coriander seeds on hexachlorocyclohexane induced lipid peroxidation in rat liver. Nutr Res 2001; 21(11): 1455-62.

[123] Chithra V and Leelamma S. Coriandrum sativum changes the levels of lipid peroxides and activity of antioxidant enzymes in experimental animals. Indian J Biochem Biophys 1999; 36(1):59-61.

[124] Moustafa AH, Ali EM, Moselhey SS, Tousson E and El-Said KS. Effect of coriander on thioacetamideinduced hepatotoxicity in rats. Toxicol Ind Health 2014; 30(7): 621-629.

[125] Dias MI, Barros L, Sousa MJ and Ferreira IC. Comparative study of lipophilic and hydrophilic antioxidants from in vivo and in vitro grown Coriandrum sativum. Plant Foods Hum Nutr 2011; 66(2): 181-186.

[126] Deepa B and Anuradha CV. Antioxidant potential of Coriandrum sativum L. seed extract. Indian J Exp Biol 2011;49(1):30-38.

[127] Harsha SN and Anilakumar KR. In vitro free radical scavenging and DNA damage protective property of Coriandrum sativum L. leaves extract. J Food Sci Technol 2014;51(8):1533-1539.

[128] El-Hela AA, Abdel-Hady NM, Dawoud GT, Hamed AM and Morsy TA. Phenolic content, antioxidant potential and Aedes aegyptii ecological friend larvicidal activity of some selected Egyptian plants. J Egypt Soc Parasitol 2013; 43(1): 215-234.

[129] Khan S, Riaz N, Afza N, Malik A, Aziz-ur-Rehman, Iqbal L and Lateef M. Antioxidant constituents from Cotoneaster racemiflora. J Asian Nat Prod Res 2009; 11(1):44-48.

[130] Khan S, Yasmeen S, Afza N, Malik A, Iqbal L, and Lateef M. Cotonoates A and B, new aromatic esters from Cotoneaster racemiflora. Z Naturforsch 2008; 63b: 1219-1222.

[131] Zengin G, Uysal A, Gunes E and Aktumsek A. Survey of phytochemical composition and biological effects of three extracts from a wild plant (Cotoneaster nummularia Fisch. et Mey.): a potential source for functional food ingredients and drug formulations. PLoS One 2014; 9(11):e113527.

[132] Al-Busafi S, Al-Riyami M, Al-Ouwaisi K and Hisham A. Screening of antioxidant and radical scavenging activities of some Omani medicinal plants. SQU Journal For Science 2007; 12 (1): 1-6. 
[133] Al-Snafi AE. The chemical constituents and therapeutic importance of Cressa cretica- A review . IOSR Journal of Pharmacy 2016; 6(6): 39-46.

[134] Pryianka L, Partap S, Verma M and Jha KK. In vitro antioxidant activity of plant extract of Cressa cretica. Der Pharmacia Lettre 2015; 7 (5):28-32.

[135] Sunita P, Jha S and Pattanayak SP. Anti-inflammatory and in vivo antioxidant activities of Cressa cretica Linn., a halophytic plant. Middle-East Journal of Scientific Research 2011; 8 (1): 129-140.

[136] Keyhani E and Keyhani J. Comparative study of superoxide dismutase activity assays in Crocus sativus L. corms. Prikl Biokhim Mikrobiol 2006; 42(1): 111-116.

[137] Al-Snafi AE. The pharmacology of Crocus sativus- A review. IOSR Journal of Pharmacy 2016; 6(6): 838.

[138] Ordoudi SA, Befani CD, Nenadis N, Koliakos GG and Tsimidou MZ. Further examination of antiradical properties of Crocus sativus stigmas extract rich in crocins. J Agric Food Chem 2009; 57(8): 3080-3086.

[139] Karimi E, Oskoueian E, Hendra R and Jaafar HZ. Evaluation of Crocus sativus L. stigma phenolic and flavonoid compounds and its antioxidant activity. Molecules 2010; 15(9):6244-6256.

[140] Montoro P, Maldini M, Luciani L, Tuberoso CI, Congiu F and Pizza C. Radical scavenging activity and LC-MS metabolic profiling of petals, stamens, and flowers of Crocus sativus L. J Food Sci 2012; 77(8): C893-900.

[141] Assimopoulou AN, Sinakos Z and Papageorgiou VP. Radical scavenging activity of Crocus sativus L. extract and its bioactive constituents. Phytother Res 2005; 19(11): 997-1000.

[142] Sariri R, Sabbaghzadeh R and Poumohamad F. In-vitro antioxidant and anti-tyrosinase activity of methanol extracts from Crocus sativus flowers. Pharmacologyonline 2011; 2: 1205-1215.

[143] Zeka K, Ruparelia KC, Continenza MA, Stagos D, Vegliò F and Arroo RR. Petals of Crocus sativus L. as a potential source of the antioxidants crocin and kaempferol. Fitoterapia 2015; 107: 128-134.

[144] Hosseinzadeh H, Sadeghnia HR, Ziaee $\mathrm{T}$ and Danaee A. Protective effect of aqueous saffron extract (Crocus sativus L.) and crocin, its active constituent, on renal ischemia-reperfusioninduced oxidative damage in rats. J Pharm Pharm Sci 2005; 8(3): 387-393.

[145] Li CY, Lee EJ and Wu TS. Antityrosinase principles and constituents of the petals of Crocus sativus. J Nat Prod 2004;67(3):437-440.

[146] Dinakaran SK, Banji D, Avasarala H and Banji O. Determination of antioxidant capacity, $\alpha$-amylase and lipase inhibitory activity of Crotalaria juncea Linn in vitro inhibitory activity of Crotalaria juncea Linn. J Diet Suppl 2014; 11(2):175-183.

[147] Al-Snafi AE. The contents and pharmacology of Crotalaria juncea- A review. IOSR Journal of Pharmacy 2016; 6(6): 77-86.

[148] Chouhan HS, Sahu AN and Singh. SK. Fatty acid composition, antioxidant, anti-inflammatory and antibacterial activity of seed oil from Crotolaria juncia Linn. Journal of Medicinal Plant Research 2011; 5(6): 984-991.

[149] Vallverdú-Queralt A, Regueiro J, Martínez-Huélamo M, Rinaldi Alvarenga JF, Leal LN and LamuelaRaventos RM. A comprehensive study on the phenolic profile of widely used culinary herbs and spices: rosemary, thyme, oregano, cinnamon, cumin and bay. Food Chem 2014; 154: 299-307.

[150] Al-Snafi AE. The pharmacological activities of Cuminum cyminum - A review. IOSR Journal of Pharmacy 2016; 6(6): 46-65.

[151] Allahghadri T, Rasooli I, Owlia P, Nadooshan MJ, Ghazanfari T, Taghizadeh M and Astaneh SD. Antimicrobial property, antioxidant capacity, and cytotoxicity of essential oil from cumin produced in Iran. J Food Sci 2010; 75(2): H54-61.

[152] Romeilah RM, Fayed SA and Mahmoud GI. Chemical compositions, antiviral and antioxidant activities of seven essential oils. Journal of Applied Sciences Research 2010; 6(1): 50-62.

[153] Rebey IB, Kefi S, Bourgou S, Ouerghemmi I, Ksouri R, Tounsi MS and Marzouk B. Ripening stage and extraction method effects on physical properties, polyphenol composition and antioxidant activities of cumin (Cuminum cyminum L.) seeds. Plant Foods Hum Nutr 2014; 69(4): 358-364.

[154] Chen Q, Gan Z, Zhao J, Wang Y, Zhang S, Li J and Ni Y. In vitro comparison of antioxidant capacity of cumin (Cuminum cyminum L) oils and their main components. Food Science and Technology 2013; 55(2): 632-637.

[155] Koppula S and Choi DK. Cuminum cyminum extract attenuates scopolamine-induced memory loss and stress-induced urinary biochemical changes in rats: a noninvasive biochemical approach. Pharm Biol 2011; 49(7): 702-708.

[156] Bettaieb I, Bourgou S, Wannes WA, Hamrouni I, Limam F and Marzouk B. Essential oils, phenolics, and antioxidant activities of different parts of cumin (Cuminum cyminum L.). J Agric Food Chem 2010; 58(19): 10410-10418 
[157] Atrooz OM. The Effects of Cuminum cyminum L and Carum carvi L seed extracts on human erythrocyte hemolysis. International Journal of Biology 2013; 592: 57-63.

[158] Aruna K, Rukkumani R, Suresh Varma P and Venugopal MP. Therapeutic role of Cuminum cyminum on ethanol and thermally oxidized sunflower oil induced toxicity. Phytotherapy Research 2005; 19(5): 416 421.

[159] Moussa AM, Emam AM, Diab YM, Mahmoud ME and Mahmoud A. Evaluation of antioxidant potential of 124 Egyptian plants with emphasis on the action of Punica granatum leaf extract on rats. International Food Research Journal 2011; 18: 535-542.

[160] Al-Snafi AE. Medical importance of Cupressus sempervirens- A review. IOSR Journal of Pharmacy 2016; 6(6): 66-76.

[161] Krishnaveni M, Amsavalli L, Chandrasekar R, Madhaiyan P and Durairaj S. Antioxidant activity of plants at Govt college of engineering campus, Salem, Tamil Nadu, India. Int J Pharm Sci Rev Res 2013 ;21(1): 160-163.

[162] Tumen I, Senol FS and Orhan IE. Evaluation of possible in vitro neurobiological effects of two varieties of Cupressus sempervirens (Mediterranean cypress) through their antioxidant and enzyme inhibition actions. Türk Biyokimya Dergisi [Turk J Biochem] 2012; 37 (1): 5-13.

[163] Boukhris M, Regane G, Yangui T, Sayadi S and Bouaziz M. Chemical composition and biological potential of essential oil from Tunisian Cupressus sempervirens L. Journal of Arid Land Studies 2012; 22(1): 329-332.

[164] Asgary S, Naderi GA, Ardekani MRS, Sahebkar A, Airin A, Aslani S, Kasher T and Emami SA. Chemical analysis and biological activities of Cupressus sempervirens var. horizontalis essential oils. Pharmaceutical Biology 2013; 51(2): 137-144.

[165] Ali ZA, Atia HA and Ibrahim NH. Possible hepatoprotective potential of Cynara scolymus, Cupressus sempervirens and Eugenia jambolana against paracetamol-induced liver Injury: In-vitro and In vivo evidence. Nature and Science 2012; 10(1): 75-86.

[166] Costa RM, Magalhăes AS, Pereira JA, Andrade PB, Valentăo P, Carvalho M and Silva BM. Evaluation of free radical-scavenging and antihemolytic activities of quince (Cydonia oblonga) leaf: A comparative study with green tea (Camellia sinensis). Food Chem. Toxicol 2009; 47: 860-865.

[167] Al-Snafi AE. The medical importance of Cydonia oblonga- A review. IOSR Journal of Pharmacy 2016; 6(6): 87-99.

[168] Fattouch S, Caboni P, Coroneo V, Tuberoso CI, Angioni A, Dessi S, Marzouki N and Cabras P. Antimicrobial activity of Tunisian quince (Cydonia oblonga Miller) pulp and peel polyphenolic extracts. J Agric Food Chem 2007; 55(3): 963-969.

[169] Hamauzu Y, Yasui H, Inno T, Kume C and Omanyuda M. Phenolic profile, antioxidant property, and anti-influenza viral activity of Chinese quince (Pseudocydonia sinensis Schneid.), quince (Cydonia oblonga Mill.), and apple (Malus domestica Mill.) fruits. J Agric Food Chem 2005; 53(4): 928-934.

[170] Silva BM, Andrade PB, Valentão P, Ferreres F, Seabra RM and Ferreira MA. Quince (Cydonia oblonga Miller) fruit (pulp, peel, and seed) and Jam: antioxidant activity. J Agric Food Chem 2004; 52(15): 47054712.

[171] Magalhães AS, Silva BM, Pereira JA, Andrade PB, Valentão P and Carvalho M. Protective effect of quince (Cydonia oblonga Miller) fruit against oxidative hemolysis of human erythrocytes. Food Chem Toxicol 2009; 47(6): 1372-1377.

[172] Pacifico S, Gallicchio M, Fiorentino A, Fischer A, Meyer U and Stintzing FC. Antioxidant properties and cytotoxic effects on human cancer cell lines of aqueous fermented and lipophilic quince (Cydonia oblonga Mill.) preparations. Food Chem Toxicol 2012; 50(11):4130-4135.

[173] Khadri A, Serralheiro MLM, Nogueira JMF, Smiti A and Araujo MEM. Antioxidant and antiacetylcholinesterase activities of essential oils from Cymbopogon schoenanthus L Spreng. Determination of chemical composition by GC-mass spectrometry and 13C NMR. Food Chemistry 2008; 109(3): 630-637.

[174] Khadri A, Neffati M, Smiti S, Falé P, Rosa A, Lino L, Luisa M, Serralheiro M, Eduarda M and Araújo M. Antioxidant, antiacetylcholinesterase and antimicrobial activities of Cymbopogon schoenanthus L. Spreng (lemon grass) from Tunisia. LWT - Food Science and Technology 2010; 43(2); 331-336.

[175] Saroja M, Santhi R and Annapoorani S. Antioxidant potential of ethyl acetate fraction of Cynodon dactylon against ELA implanted Swiss albino mice. Int J Pharm Biol Sci 2012; 3(2):415-419.

[176] Albert-Baskar A, Numair KS, Alsaif MA and Ignacimuthu S. In vitro antioxidant and antiproliferative potential of medicinal plants used in traditional Indian medicine to treat cancer. Redox Rep 2012; 17(4): $145-156$. 
[177] Jananie RK, Priya V and Vijayalakshmi K. In vitro assessment of free radical scavenging activity of Cynodon dactylon. J Chem Pharm Res 2011; 3(4): 647-654.

[178] Thiruvengada Rajan V S, Ellaiah P and Madhusudhana Chetty C. In vitro antioxidant and alpha-amylase inhibitory activity of isolated compounds from ethyl acetate extract of Cynodon dactylon and Piper betle. Int J Pharm and Ind Res 2011; 1(4): 261-265.

[179] Nagulendran KR, Velavan S and Mahesh R. In vitro antioxidant activity and total polyphenolic content of Cyperus rotundus rhizomes. E- Journal of Chemistry 2007; 4(3): 440-449.

[180] Bashir A, Sultana B, Akhtar FH, Munir A, Amjad M and ul Hassan Q. Investigation on the antioxidant Activity of Dheela grass (Cyperus rotundus). African Journal of Basic \& Applied Sciences 2012;4 (1): $1-6$. 